\title{
Unravelling the Extent of Diversity within the Iberian Medicinal Leeches (Hirudinea: Hirudo) Using Molecules and Morphology
}

\author{
Andrés Arias ${ }^{1, *(1)}$, Victor Surugiu ${ }^{2}\left(\mathbb{D}\right.$, Rafael Carballeira ${ }^{3}{ }^{\circledR}$, Oana Paula Popa ${ }^{4}$, Luis Ovidiu Popa ${ }^{4}$ and \\ Serge Utevsky ${ }^{5}$ (i)
}

check for

updates

Citation: Arias, A.; Surugiu, V.; Carballeira, R.; Popa, O.P.; Popa, L.O.; Utevsky, S. Unravelling the Extent of Diversity within the Iberian Medicinal Leeches (Hirudinea: Hirudo) Using Molecules and Morphology. Biology 2021, 10, 315. https://doi.org/10.3390/ biology10040315

Academic Editor: Ettore Randi

Received: 12 March 2021

Accepted: 6 April 2021

Published: 9 April 2021

Publisher's Note: MDPI stays neutral with regard to jurisdictional claims in published maps and institutional affiliations.

Copyright: (C) 2021 by the authors Licensee MDPI, Basel, Switzerland. This article is an open access article distributed under the terms and conditions of the Creative Commons Attribution (CC BY) license (https:// creativecommons.org/licenses/by/ $4.0 /)$.
1 Departamento de Biología de Organismos y Sistemas (Zoología), Universidad de Oviedo, 33071 Oviedo, Spain

2 Faculty of Biology, "Alexandru Ioan Cuza" University of Iasi, 700505 Iaşi, Romania; vsurugiu@uaic.ro

3 Centro de Investigacións Cientificas Avanzadas (CICA), Facultade de Ciencias, Universidade da Coruña, 15071 A Coruña, Spain; rafael.carballeira@gmail.com

4 Grigore Antipa National Museum of Natural History, Sos. Kiseleff Nr. 1, 011341 Bucharest, Romania; oppopa@antipa.ro (O.P.P.); popaluis@antipa.ro (L.O.P.)

5 Department of Zoology and Animal Ecology, V. N. Karazin Kharkiv National University, Maidan Svobody 4, 61022 Kharkiv, Ukraine; serge.utevsky@karazin.ua

* Correspondence: ariasandres@uniovi.es

Simple Summary: During the last decade, our understanding of the biogeography of WesternPalaearctic leeches (genus Hirudo) has begun to unravel, unveiling their diversity in practically all of Europe, except for its westernmost peninsula, Iberia. We discovered for the first time H. verbana in Spain and conducted an integrative approach (combining morphology, anatomy, ecology with genetics) to characterize the newly recorded Iberian populations. We found two endemic and geographically separated Iberian lineages of H. verbana. One of them is easily distinguished by its distinctive colour-pattern and is described as H. verbana bilineata ssp. nov. We established its phylogenetic relationships with other European Hirudo spp. and confirmed the presence of a second species in Iberia, H. troctina. The provided distribution pattern of medicinal leeches contributes to a better understanding of the complexity of the Iberian Peninsula as a glacial refugium/cradle for endemisms, sheltering species populations that began to settle throughout the Pleistocene. Finally, we highlight the urgent need for implementing conservation measures to reverse the evident decline of Iberian populations of medicinal leeches.

Abstract: Until the beginning of the 21st century, the famous medicinal leech was thought to be represented by only one species, Hirudo medicinalis. However, recent publications have demonstrated that under that name, at least five different species of medicinal leeches were hidden. During the last decade, the biogeography of Western-Palaearctic leeches has begun to unravel, untangling their diversity in practically all of Europe, except for its westernmost peninsula, Iberia. Hirudo medicinalis has been repeatedly reported from Iberia, but those records were considered questionable. We discovered H. verbana in northern Spain, constituting its first record in Iberia. Using an integrative approach (combining morpho-anatomical data and molecular analyses using three genes, COI,12S rRNA, and ITS2), two endemic and geographically separated Iberian lineages have been found. One of them is easily distinguished by its distinctive colour-pattern and is described as $H$. verbana bilineata ssp. nov. We characterized the new subspecies morphologically, ecologically, and genetically. We also established its phylogenetic relationships with other European Hirudo spp. and confirm the presence of $H$. troctina in Iberia, occurring as far as $43^{\circ}$ lat. N. Iberian H. verbana records constitute its westernmost known distribution to date. The provided distribution pattern of $H$. verbana contributes to a better understanding of the complexity of Iberia as a glacial refugium/cradle for endemisms, harbouring populations with a high degree of genetic structure that began to settle throughout the Pleistocene. Iberian Hirudo populations are declining in recent decades and there is an urgent need to assess their conservation status and to initiate conservation measures to reverse their decline. 
Keywords: Annelida; biodiversity; speciation; COI mtDNA; 12S rRNA; ITS2; conservation; ESU; Europe; taxonomy

\section{Introduction}

The medicinal leech sensu lato-Hirudo medicinalis Linnaeus, 1758-is one of the first described species of annelids and the most well-known representative of the subclass Hirudinea, which was named and originally defined by this species. Medicinal leeches are haematophagous ectoparasites of vertebrates and are widely used in medicine and as model organism in biology and physiology [1]. Hirudo medicinalis has been traditionally considered as a single species; however, several recent publications have demonstrated that what was considered as $\mathrm{H}$. medicinalis actually comprises at least five different species: H. medicinalis, Hirudo troctina Johnson, 1816, Hirudo verbana Carena, 1820, Hirudo orientalis Utevsky \& Trontelj, 2005 and Hirudo sulukii Saglam, Saunders, Lang and Shain, 2016 [1-7]. The biogeography of the Western Palaearctic medicinal leeches has been recently revised by Utevsky et al. [6]. These authors stated that $H$. medicinalis is distributed from Britain and southern Norway to the southern Urals and probably as far as the Altai Mountains; H. verbana is distributed from Switzerland and Italy to Turkey and Uzbekistan; H. orientalis occurs in the Transcaucasian countries, Iran, and Central Asia; H. troctina is present in northwestern Africa and southern Iberia [6], and finally H. sulukii is, so far, only known from south-eastern Anatolia [7]. Furthermore, the aforementioned authors [6] also concluded that climate conditions play an important role in the distribution patterns of the medicinal leeches in the Western Palaearctic region.

The Iberian Peninsula or Iberia is the third largest European peninsula and constitutes the south-westernmost part of Europe. It is bordered on the southeast and east by the Mediterranean Sea and on the north, west, and southwest by the Atlantic Ocean. The Pyrenees Mountains are situated along the northeast edge of Iberia, where it adjoins the rest of Europe. Its southern tip is very close to the northwest coast of Africa. Due to these geographical features, Iberia harbours different climate types, outstanding the Oceanic climate from the North to north-western part and the Mediterranean one in the Centre and southern regions. It also presents both the Alpine and the Subarctic climate in the higher mountains of northern Spain (mainly the Cantabrian Mountains and the Pyrenees) [8]. From the biogeographical perspective, the Iberian Peninsula is considered one of the most important Pleistocene glacial refugia of the European subcontinent [9-11]. Iberia harbours a remarkable biological diversity, including endemic ectoparasites [12].

Two species of medicinal leeches have been repeatedly reported from Iberia: $\mathrm{H}$. medicinalis, mostly in the northern part [6,13-17], and H. troctina, mostly in the southern Iberian Peninsula [18-22]. However, based upon current knowledge on the taxonomy and biogeography of the European medicinal leeches, the Iberian records of $H$. medicinalis should be considered as questionable [6]. Furthermore, the climate conditions of North-West and North Iberia might favour the occurrence of $H$. verbana in this area, as has been previously hypothesized by Utevsky et al. [6].

During the course of our investigations, we discovered two populations of Hirudo from north-western and north-central Spain, characterized by a pigmentation pattern distinct from the typical European Hirudo spp. (i.e., H. medicinalis, H. verbana and H. troctina), with a ventral pattern closely resembling of $H$. verbana and a distinctive dorsal pattern, consisting of two paired lines that run parallel at the lateral margins of the dorsum along the entire length of the leech (herein referred to as "bilineated"). Furthermore, we also found several populations bearing the typical colour pattern assigned to $H$. verbana in Galicia (northwestern Spain).

The main goal of the present paper is to assess the actual diversity and distribution of the Iberian medicinal leeches, in order to fill the knowledge gap on the biogeography of south European Hirudo spp. This study aims as well to reveal the phylogenetic relationships 
between the Iberian and the other European medicinal leeches by using two mitochondrial genes and various morpho-anatomical characters.

\section{Materials and Methods}

\subsection{Species Sampling and Morphological Examination}

The search for Hirudo populations in the field took place from May 2015 to October 2017. Successful collections of Hirudo spp. were carried out from August 2015 to July 2016 at several locations in the northern Iberian Peninsula (Figure 1). The leeches were prepared for preservation in situ, first relaxed in an ascending series of graded ethanol and afterwards fixed in 10\% formalin for morphological studies and in 100\% ethanol for genetic studies. Thereafter, collected specimens were brought to the laboratory for subsequent taxonomical and genetic analysis. All localities with collection data and additional information are fully listed in Table 1. Initially the specimens were sorted into two groups or morphotypes according to their colour pattern: "typical" - the originally described pattern in H. verbana, and "bilineated" - dorsal colouration consisting of two paired lines that run parallel at the lateral margins of dorsum, along the entire length of the leech.
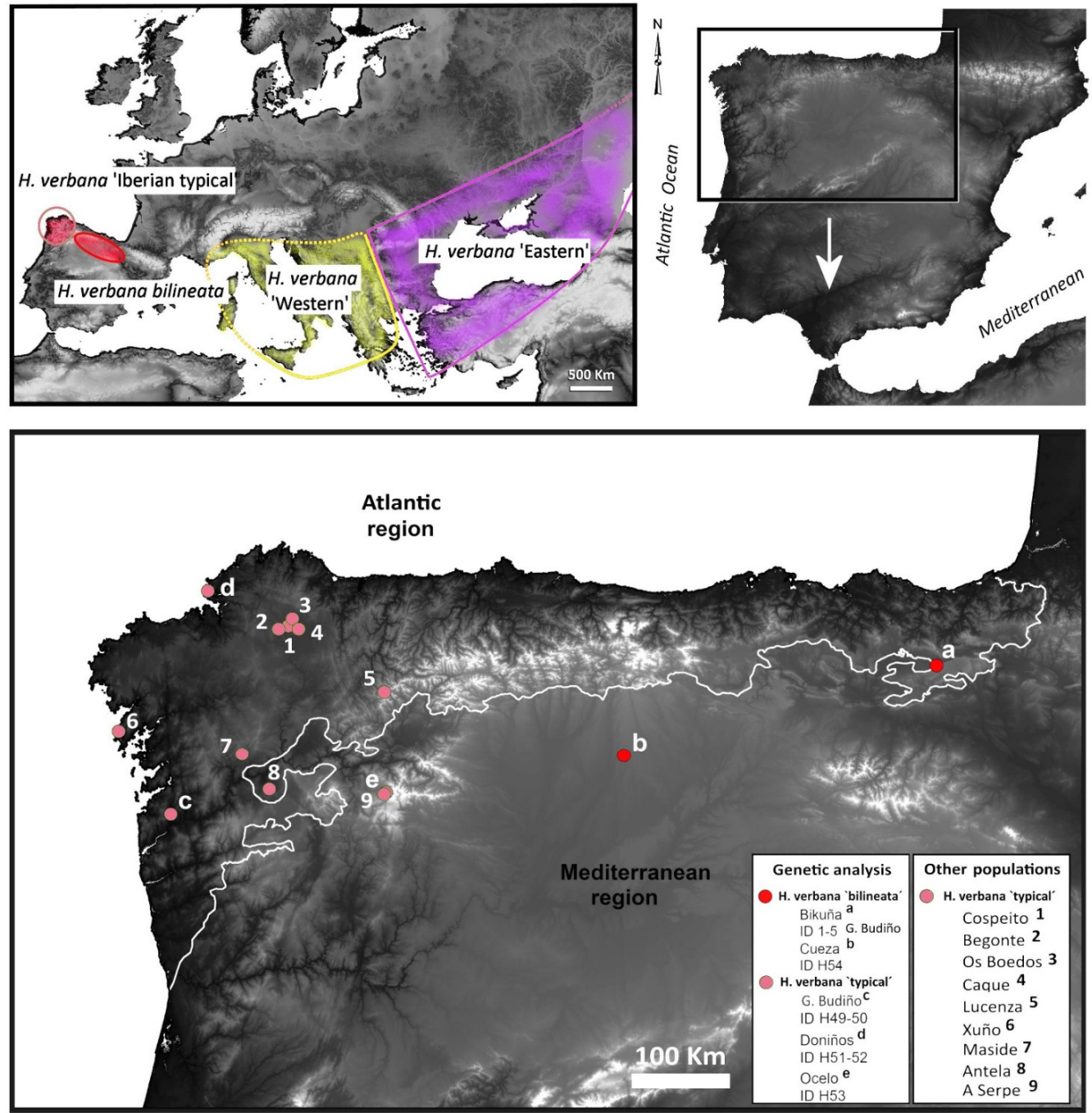

Figure 1. Geographical distribution of Hirudo verbana in Europe (top left corner) and in Iberian Peninsula, showing genetic-studied populations (a-e) and others (1-9) (bottom) [Elevation map SRTM 90 m]. 
Table 1. Location of studied Spanish samples used in this analysis with combined COI and $12 \mathrm{~S}$ mt markers.

\begin{tabular}{|c|c|c|c|c|}
\hline Sample ID & Species & Morphotype & Locality & Collector /Date \\
\hline ANN003 & Hirudo verbana & "bilineated" & $\begin{array}{c}\text { Bikuña pond, } 42^{\circ} 50^{\prime} 16^{\prime \prime} \mathrm{N}, 2^{\circ} 19^{\prime} 24^{\prime \prime} \\
\text { W, Álava, Basque Country }\end{array}$ & A. Arias 26 September 2015 \\
\hline ANN004 & H. verbana & "bilineated" & $\begin{array}{c}\text { Bikuña pond, } 42^{\circ} 50^{\prime} 16^{\prime \prime} \mathrm{N}, 2^{\circ} 19^{\prime} 24^{\prime \prime} \\
\text { W, Álava, Basque Country }\end{array}$ & A. Arias 26 September 2015 \\
\hline ANN005 & H. verbana & "bilineated" & $\begin{array}{c}\text { Bikuña pond, } 42^{\circ} 50^{\prime} 16^{\prime \prime} \mathrm{N}, 2^{\circ} 19^{\prime} 24^{\prime \prime} \\
\text { W, Álava, Basque Country }\end{array}$ & A. Arias 26 September 2015 \\
\hline ANN006 & H. verbana & "bilineated" & $\begin{array}{c}\text { Bikuña pond, } 42^{\circ} 50^{\prime} 16^{\prime \prime} \mathrm{N}, 2^{\circ} 19^{\prime} 24^{\prime \prime} \\
\text { W, Álava, Basque Country }\end{array}$ & A. Arias 26 September 2015 \\
\hline ANN007 & H. verbana. & "bilineated" & $\begin{array}{c}\text { Cueza pond, } 42^{\circ} 25^{\prime} 35^{\prime \prime} \mathrm{N}, 4^{\circ} 55^{\prime} 56^{\prime \prime} \mathrm{W}, \\
\text { León, Castilla y León }\end{array}$ & R. Carballeira 22 May 2016 \\
\hline ANN008 & H. verbana & "typical” & $\begin{array}{c}\text { Gándaras de Budiño, } 42^{\circ} 06^{\prime} 43^{\prime \prime} \text { N, } \\
8^{\circ} 37^{\prime} 48^{\prime \prime} \text { W, Pontevedra, Galicia }\end{array}$ & R. Carballeira 13 June 2015 \\
\hline ANN009 & H. verbana & "typical" & $\begin{array}{c}\text { Gándaras de Budiño, } 42^{\circ} 06^{\prime} 43^{\prime \prime} \mathrm{N}, \\
8^{\circ} 37^{\prime} 48^{\prime \prime} \mathrm{W} \text {, Pontevedra, Galicia }\end{array}$ & R. Carballeira 13 June 2015 \\
\hline ANN010 & H. verbana & "typical" & $\begin{array}{c}\text { Doniños Lake, } 42^{\circ} 29^{\prime} 31^{\prime \prime} \text { N, } 8^{\circ} 18^{\prime} 44^{\prime \prime} \\
\text { W, A Coruña, Galicia }\end{array}$ & R. Carballeira 13 June 2015 \\
\hline ANN011 & H. verbana & "typical" & $\begin{array}{c}\text { Doniños Lake, } 42^{\circ} 29^{\prime} 31^{\prime \prime} \text { N, } 8^{\circ} 18^{\prime} 44^{\prime \prime} \\
\text { W, A Coruña, Galicia Spain }\end{array}$ & R. Carballeira 13 June 2015 \\
\hline ANN012 & H. verbana & "typical" & $\begin{array}{c}\text { Ocelo, } 42^{\circ} 13^{\prime} 36^{\prime \prime} \mathrm{N}, 6^{\circ} 52^{\prime} 22^{\prime \prime} \mathrm{W}, \\
\text { Orense, Galicia }\end{array}$ & R. Carballeira 13 June 2015 \\
\hline
\end{tabular}

Additionally, historical collections of Hirudo sp. specimens from different localities of the Iberian Peninsula, deposited in the Museo Nacional de Ciencias Naturales (MNCN) of Madrid (Spain) and the Department of Biology of Organisms and Systems (BOS) of the University of Oviedo (Spain), were examined. In the "Material Examined" section of the species description, all localities with collection data and additional information are fully listed. All reported species are based upon verified records by the authors, through the evaluation of direct field results and preserved physical evidence that exhibits diagnostic features. Additional information used to assess the diversity of medicinal leeches in Spain was obtained from scientific published data [1-45].

Overall morphology and anatomy were examined under both dissecting stereomicroscope and compound light microscope. Selected specimens were dissected dorsally and ventrally for anatomical study. Line drawings were made with the aid of a camera lucida and digital photography. Photomicrographs were taken with a Leica DFC310FX camera mounted on a Leica M205FA stereomicroscope.

To define the specific or subspecific identity of the studied taxa, we used an integrative approach including tree topologies, pairwise uncorrected p-distance, Automatic Barcoding Gap Discovery (ABGD), and morphological and anatomical data. Measurements and counts in the descriptions are of the holotype; the range for the paratypes is given in parentheses; terminology of general morphology follows $[1,3,36]$. The specimens examined in this study are deposited in the MNCN of Madrid and the "Grigore Antipa" National Museum of Natural History of Bucharest, Romania (MGAB).

\subsection{Molecular Methods}

Ten $100 \%$ ethanol fixed specimens of Iberian Hirudo from the two morphotypes ("typical" and "bilineated") collected from five Spanish localities (Bikuña, Cueza, Gándaras de Budiño, Doniños, and Ocelo; see Figure 1 and Table 1) were prepared for genetic analysis. The specimens collected for molecular analysis were deposited in the Annelida Collection of the "Grigore Antipa" National Museum of Natural History of Bucharest (Romania, MGAB), under the following inventory numbers: ANN003-ANN012. Tissue samples were taken 
from the caudal sucker to avoid contamination from gut contents. Approximately half of the caudal sucker was removed with a scalpel and the tissue fragments were processed thereafter. Genomic DNA was extracted using the Isolate II Genomic DNA Kit (Bioline, London, UK) following manufacturer specifications. A partial COI fragment was amplified using the universal PCR primers LCO1490 and HCO2198 [37]. The mitochondrial 125 rRNA gene and the nuclear Internal Transcribed Spacer (ITS2) gene were amplified with primers developed by [1] and references therein.

The PCR reactions were performed in a total volume of $50 \mu \mathrm{L}$ containing $10 \mathrm{ng}$ of DNA template, 1X Green GoTaq ${ }^{\circledR}$ Flexi Buffer, $2.5 \mathrm{mM} \mathrm{MgCl2}$, each dNTP at $0.1 \mathrm{mM}$, $0.5 \mu \mathrm{M}$ of each primer and 1.5 units of GoTaq ${ }^{\circledR}$ DNA polymerase (Promega, Madison, WI, USA). The PCR products were isolated from samples presenting clean and visible bands on $0.5 \mu \mathrm{g}$ ml-1 ethidium bromide stained agarose gel, using the FavorPrep ${ }^{\mathrm{TM}} \mathrm{Gel} / \mathrm{PCR}$ Purification Kit (FAVORGEN ${ }^{\circledR}$ Biotech Corp., Changzhi, Taiwan), following manufacturer specifications. Macrogen (Seoul, Korea) services were used for sequencing.

The resulting sequences for both genes were edited and aligned in CodonCode Aligner version 3.7.1. (CodonCode Corporation, Dedham, MA, USA). For this study, another 45 sequences of $\mathrm{COI}$ and $12 \mathrm{~S}$ for all studied species of Hirudo, as well as 28 sequences of the Internal Transcribed Spacer (ITS2) of H. verbana and H. troctina, and one outgroup, were retrieved from GenBank (Table A1).

The unique haplotypes in the whole data set were identified in DnaSP v.5 [38] and were used for all the subsequent analysis. Genetic distances between groups (either recognized species or morphotypes of H. verbana) were calculated in MEGA7 [39]. A median-joining network was constructed in PopART v. 1.7. [40], with haplotypes represented by circles with sizes proportional to the number of individuals, while different colours were used to depict the geographic distribution of the haplotypes.

In order to evaluate the phylogenetic relationships between Iberian Hirudo and its related species, we performed a phylogenetic analysis by Bayesian inference using MrBayes v3.2.6 [41] on the platform CIPRES Science Gateway (https:/ / www.phylo.org accessed on 15 June 2020). First, we used PartitionFinder v.2 [42] to identify the optimum partition scheme and substitution models for the concatenated sequences and preliminary exploratory analyses were performed for each gene fragment. As the resulting tree topologies did not contradict each other, we decided to perform the further analysis on the combined $\mathrm{COI}$ and $12 \mathrm{~S}$ mitochondrial sequences. Based on the proposed partitions/models, we used one partition for COI codon 1 and 3 and 12S, with the K81UF + I + G model of molecular evolution, while a second partition was used for COI codon 2 with the K81UF+G model. We ran two simultaneous analyses with ten million generations each, sampling every 1000th generation. Gaps were treated like missing data and default settings were used for all other parameters.

Consensus trees obtained by summarizing the posterior sample of trees to produce a maximum clade credibility tree with default burn-in value generated using TREEANNOTATOR [43]. FIGTREE v1.4.4 [44] was used for visualising trees and producing publicationquality figures.

The Automatic Barcoding Gap Discovery (ABGD) [45] analysis was used for molecular species delimitation as implemented on the web server http:/ / wwwabi.snv.jussieu. $\mathrm{fr} / \mathrm{public} / \mathrm{abgd} / \mathrm{abgdweb} . \mathrm{html}$ (accessed on 18 June 2020). A sequence alignment was submitted and the analysis was performed on the Jukes-Cantor and Kimura 2-P genetic distances matrix, with the relative gap width between 0.5 and 1.5 , and a prior intraspecific divergence (from Pmin to Pmax) between $0.1 \%$ to $10 \%$, with 10 steps.

\section{Results}

\subsection{Phylogenetic Reconstruction}

Final alignments of the concatenated 55 sequences of the two analysed mitochondrial markers, COI (606 bp) and $12 \mathrm{~S}$ (286 bp) rRNA, revealed 27 unique haplotypes of the treated Hirudo spp. Two new haplotypes of COI and $12 \mathrm{~S}$ rRNA ("H 1" and "H 2") have been 
identified in the Hirudo analysed samples from Spain. "H 1" was found in all specimens of the "bilineated" morphotype from the Basque Country and Léon, and " $\mathrm{H} 2$ " in all specimens of the "typical" form from Galicia (Table 1). We identified nine parsimony informative sites in the two haplotypes, six of which were found in the COI portion of the combined sequences (all mutated positions were producing differences in the aminoacid sequence), while only three mutated positions were found in the $12 \mathrm{~S}$ portion of the combined sequences. The Bayesian Analysis of the two concatenated mitochondrial genes supports the monophyly of the group formed by the two Iberian morphotypes of Hirudo, which are sister to H. verbana (Figure 2). Our analyses confirmed the two previously reported and well-supported clades of H. verbana (i.e., the Eastern and Western Phylogroups sensu, Trontelj and Utevsky [4]) and evidenced the existence of a new phylogroup, which is herein designated as the "Iberian phylogroup" (Figure 2). The new Iberian phylogroup of $H$. verbana is composed of all collected specimens from Spain (Figure 1). The internal resolution of this phylogroup, comprising the "bilineated" and the "typical" morphotypes, was robustly supported in our analysis (BS $=99-100 \%$ ).

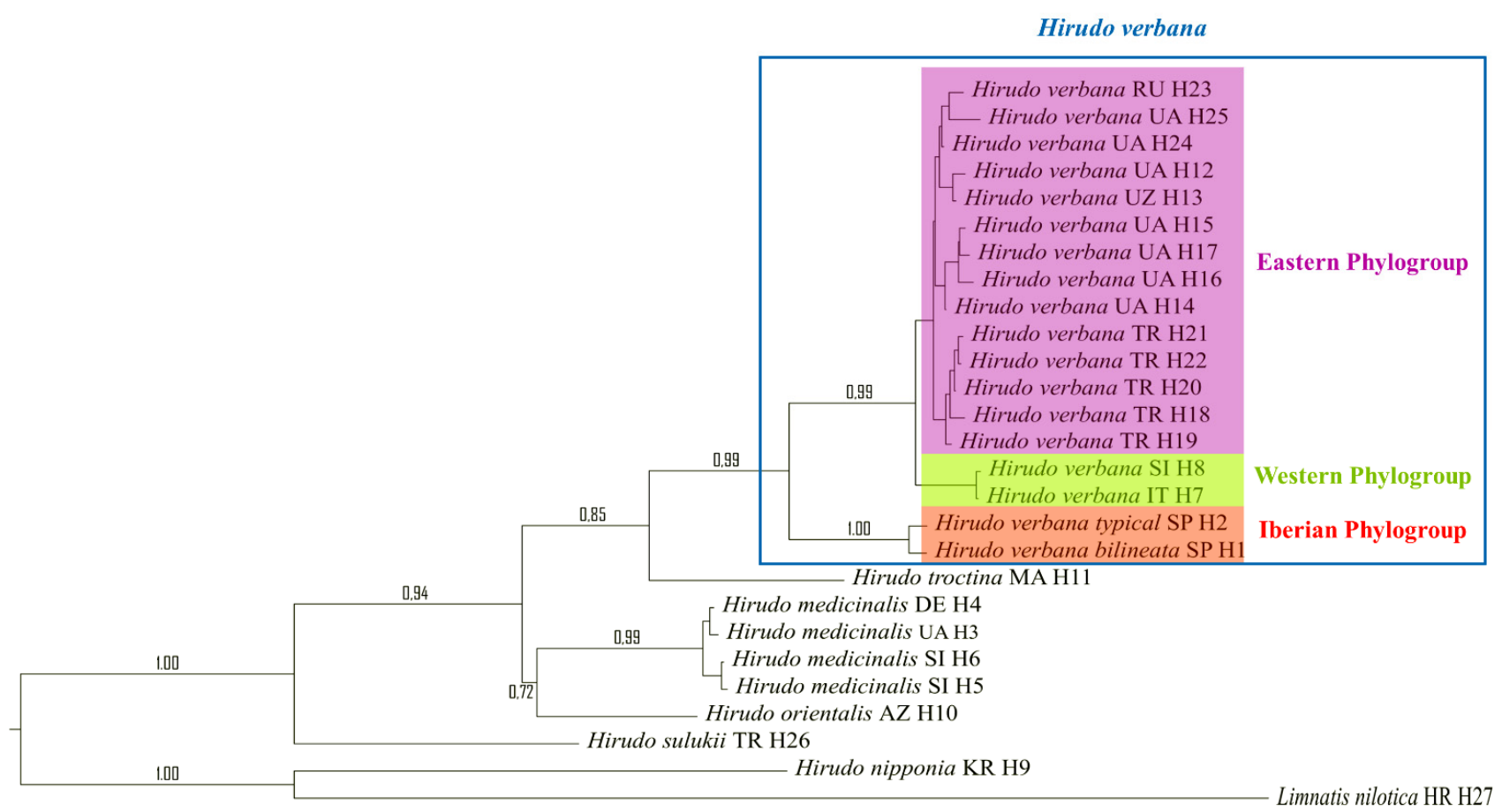

Figure 2. Phylogenetic relationship of Hirudo spp. based on Bayesian inference for the combined COI and 12S mitochondrial markers.

The Median-Joining network showing the relationships among haplotypes of H. verbana is depicted in Figure 3. It can be observed that the nucleotide differences are limited to one or two mutational positions between different haplotypes in each lineage. For the Eastern $H$. verbana lineage, we obtained a dominant haplotype $\mathrm{H} 12$, found in individuals from south-western, southern, and north-eastern Ukraine, the Krasnodar, and Stavropol territories of the Russian Federation, one of the most important centres of commercial harvesting with medicinal leeches, where the releasing of animals after their use may change the intraspecific genetic structure. The star-like shape of the network with a rarer haplotype radiating from the common haplotype obtained for the Eastern lineage suggests a fast range expansion from a relatively small founding population. The Western lineage is represented by two haplotypes, which differ by only one mutated position. The new Iberian phylogroup comprises two haplotypes with nine mutations between them (see Figure 3). 


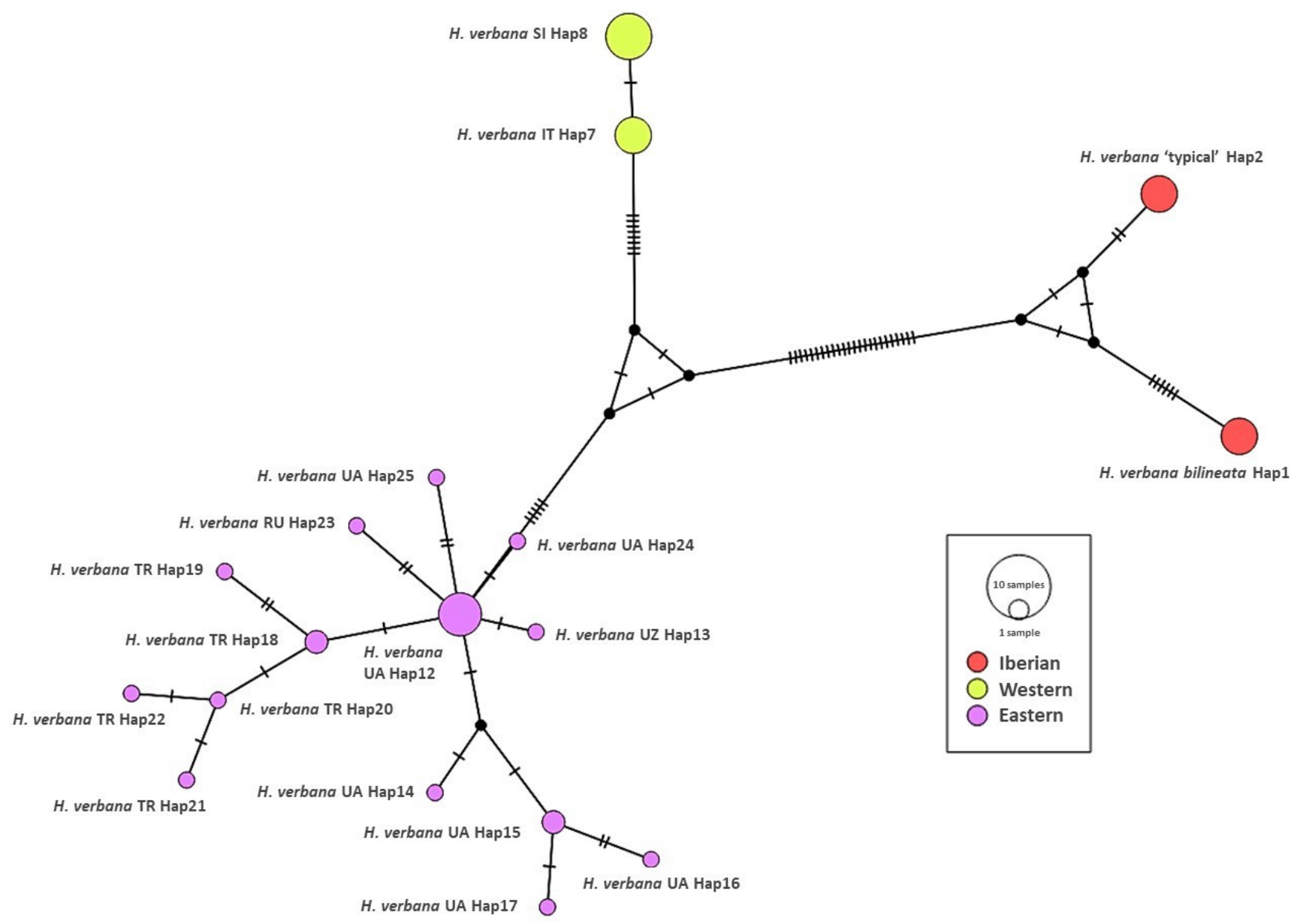

Figure 3. Median joining network of Hirudo verbana. The bars on branch length represent the number of substitutions.

The calculated genetic distances between groups using the p-distance method are presented in Table 2. The distances between Iberian "bilineated" and "typical" morphotypes of H. verbana and the two Eastern and Western phylogroups of the same species are between 0.039 and 0.043 . The genetic distance between the two Spanish morphotypes (1\%) is not significantly different from the genetic distance between the Eastern and Western phylogroups of $H$. verbana $(1.80 \%)$, considering the standard error. The pairwise genetic distances computed between all the other analysed species ranged from $7.30 \%$ (H. orientalis-H. medicinalis) to $10.30 \%$ (H. sulukii-H. troctina) and to $20.80 \%$ (H. nipponia-H. orientalis), and were significantly higher than the distances between the $H$. verbana groups.

The Automatic Barcoding Gap Discovery (ABGD) analysis correctly identified all used species when the prior intraspecific divergence varied between $2.20 \%$ and $3.60 \%$. When this prior value was as low as $1.30 \%$, the analysis identified the Iberian clade as a distinct group from all the other $H$. verbana samples. Finally, at $0.70 \%$ intra-specific divergence, the analysis identified the Western and Eastern lineages of $H$. verbana, as well as the "bilineated" and "typical" morpho-groups from Spain. The same result (groups separating at the same levels of intraspecific genetic divergence) was obtained when using Jukes-Cantor or Kimura 2-P distances and for values of the relative gap width between 0.5 and 1.5. 
Table 2. The p-distances calculated between groups of Hirudo based on haplotypes of concatenated COI and $12 \mathrm{~S}$ sequences. Standard error estimate(s) are shown above the diagonal.

\begin{tabular}{|c|c|c|c|c|c|c|c|c|c|c|}
\hline & 1 & 2 & 3 & 4 & 5 & 6 & 7 & 8 & 9 & 10 \\
\hline $1 \mathrm{H}$. medicinalis & & $1.3 \%$ & $0.9 \%$ & $0.9 \%$ & $0.9 \%$ & $0.9 \%$ & $0.9 \%$ & $0.9 \%$ & $0.9 \%$ & $1.4 \%$ \\
\hline 2 H. nipponia & $20 \%$ & & $1.4 \%$ & $1.3 \%$ & $1.3 \%$ & $1.3 \%$ & $1.3 \%$ & $1.3 \%$ & $1.3 \%$ & $1.4 \%$ \\
\hline 3 H. orientalis & $7.3 \%$ & $20.8 \%$ & & $0.9 \%$ & $0.9 \%$ & $0.9 \%$ & $0.9 \%$ & $0.9 \%$ & $1 \%$ & $1.4 \%$ \\
\hline 4 H. troctina & $8 \%$ & $18.9 \%$ & $8.4 \%$ & & $0.9 \%$ & $0.9 \%$ & $0.9 \%$ & $0.9 \%$ & $1 \%$ & $1.4 \%$ \\
\hline $\begin{array}{l}5 \text { H. verbana Eastern } \\
\text { Phylogroup }\end{array}$ & $8.3 \%$ & $19.5 \%$ & $8.1 \%$ & $8.6 \%$ & & $0.4 \%$ & $0.6 \%$ & $0.6 \%$ & $1 \%$ & $1.4 \%$ \\
\hline $\begin{array}{l}6 \text { H. verbana Western } \\
\text { Phylogroup }\end{array}$ & $7.7 \%$ & $18.8 \%$ & $7.6 \%$ & $7.7 \%$ & $1.8 \%$ & & $0.7 \%$ & $0.7 \%$ & $1 \%$ & $1.4 \%$ \\
\hline $\begin{array}{l}7 \text { H. verbana verbana } \\
\text { (Iberian) }\end{array}$ & $7.5 \%$ & $18.8 \%$ & $7.5 \%$ & $7.6 \%$ & $3.9 \%$ & $4.1 \%$ & & $0.3 \%$ & $1 \%$ & $1.4 \%$ \\
\hline 8 H. verbana bilineata & $7.7 \%$ & $19.6 \%$ & $7.6 \%$ & $7.9 \%$ & $4.3 \%$ & $4.3 \%$ & $1 \%$ & & $1 \%$ & $1.4 \%$ \\
\hline 9 H. sulukii & $9.4 \%$ & $19.7 \%$ & $9.6 \%$ & $10.3 \%$ & $10 \%$ & $9.8 \%$ & $9.7 \%$ & $10 \%$ & & $1.4 \%$ \\
\hline 10 Limnatis cf. nilotica & $23.1 \%$ & $24.7 \%$ & $22.9 \%$ & $22.9 \%$ & $23.7 \%$ & $23.4 \%$ & $23.2 \%$ & $23.4 \%$ & $22.5 \%$ & \\
\hline
\end{tabular}

The ABGD analyses revealed the existence of cryptic diversity within the studied samples of $H$. verbana. These analyses recovered the same four groups as in the phylogenetic analyses. Thus, $H$. verbana is shown to be formed by a complex of four phylogroups (Eastern Group, Western Group, Iberian "typical", and Iberian "bilineated"). Morphologically, based on the knowledge we have to date, the first three are virtually indistinguishable (i.e., "cryptic") and are considered as belonging to the nominal morpho-subspecies (H. verbana verbana), while the last one can be clearly differentiated from the other three and thus is herein described as a new subspecies.

\subsection{Taxonomic Account}

Systematic position according to Tessler et al. [23].

Phylum Annelida Lamarck, 1809

Class Clitellata Michaelsen, 1919

Subclass Hirudinea Lamarck, 1818

Order Hirudinida Siddall et al., 2001

Suborder Hirudiniformes Caballero, 1952

Genus Hirudo Linnaeus, 1758

Species Hirudo verbana Carena, 1820

Hirudo verbana bilineata ssp. nov.

Type material: Holotype: One adult individual preserved in ethanol, $56 \mathrm{~mm}$ long, $10.5 \mathrm{~mm}$ wide, Bikuña pond, $855 \mathrm{~m}$ altitude, $42^{\circ} 50^{\prime} 16^{\prime \prime} \mathrm{N}, 2^{\circ} 19^{\prime} 24^{\prime \prime} \mathrm{W}$, Bikuña (San Millán), Álava, Basque Country, Spain (MNCN 16.02/123).

Paratypes: Six adult specimens preserved in ethanol, ranging from 42.5 to $76 \mathrm{~mm}$ in length, and from 6 to $9.5 \mathrm{~mm}$ in width, same data as holotype (MNCN 16.02/124).

Non-type material: Three adult specimens, same data as holotype; 12 adult specimens from Cueza pond, $913 \mathrm{~m}$ altitude, $42^{\circ} 2^{\prime} 35^{\prime \prime} \mathrm{N}, 4^{\circ} 55^{\prime} 56^{\prime \prime} \mathrm{W}$, Celada de Cea, León, Spain (BOS Collection; MNCN); 4 specimens, Zuazo de Cuartango, Kuartango Valley, 555-1000 m altitude, Álava, Basque Country, Spain, Coll. F.J. Ocharan 1980 (BOS Invertebrate Collection, University of Oviedo).

Comparative material: Hirudo verbana "typical": Location data and other important information is fully listed below in the section of "Hirudo verbana verbana Iberian typical".

Etymology: The subspecific name is derived from the Latin meaning "with two lines", with reference to the dorsal colour pattern consisting of two thin, paired lines that run parallel on both sides of dorsum along its whole length (Figures 4 and 5). 

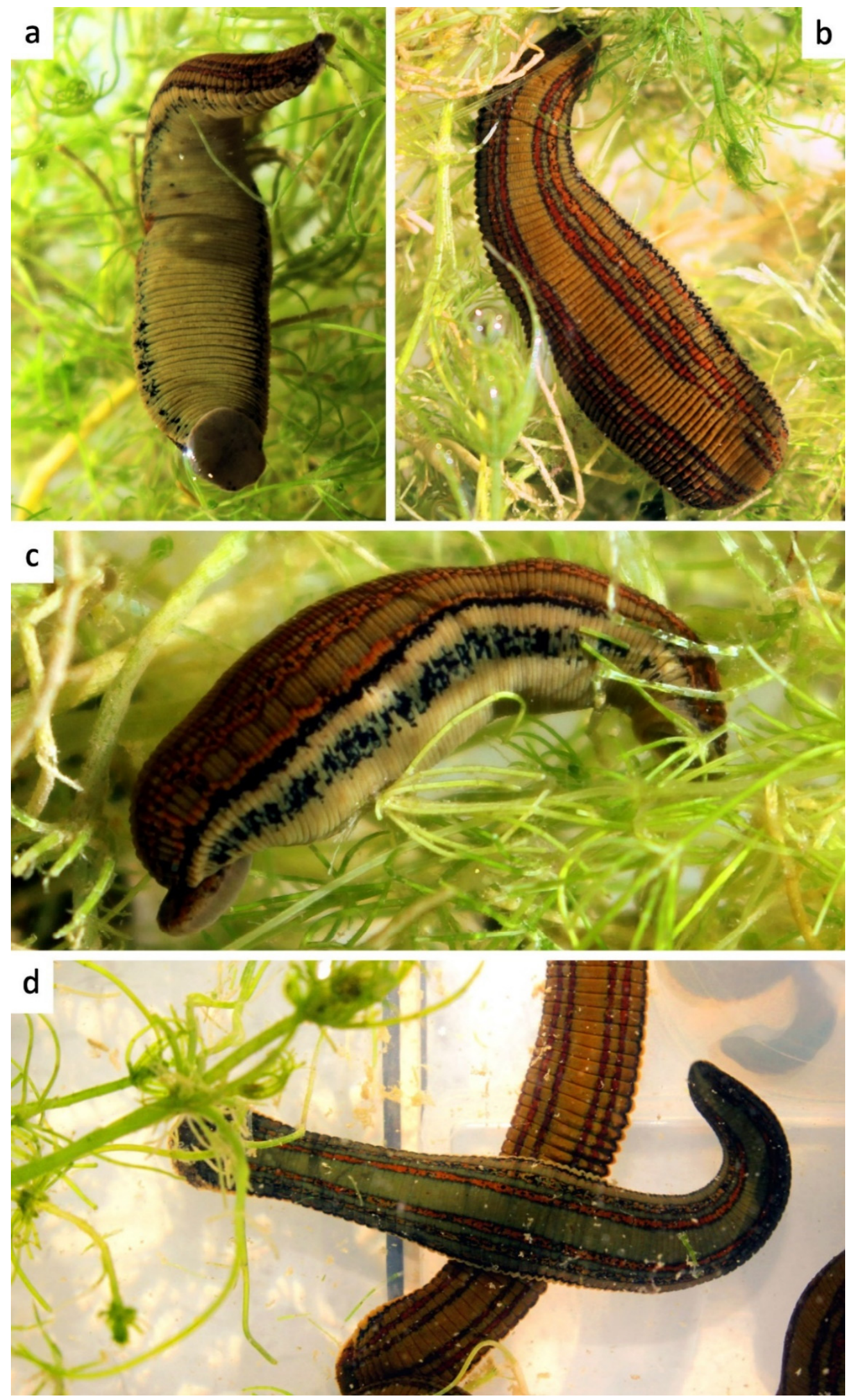

Figure 4. Habitus and colour pattern of living specimens of Hirudo verbana bilineata ssp. nov. from the type locality. $(\mathbf{a}, \mathbf{b})$ Ventral and dorsal views of holotype; (c) lateral view of topotype specimen; (d) topotype specimens with greenish background-colour (above) and with brownish one (below). 
a

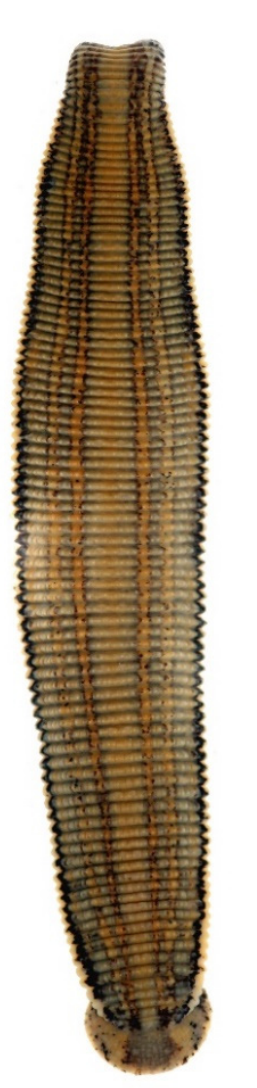

b
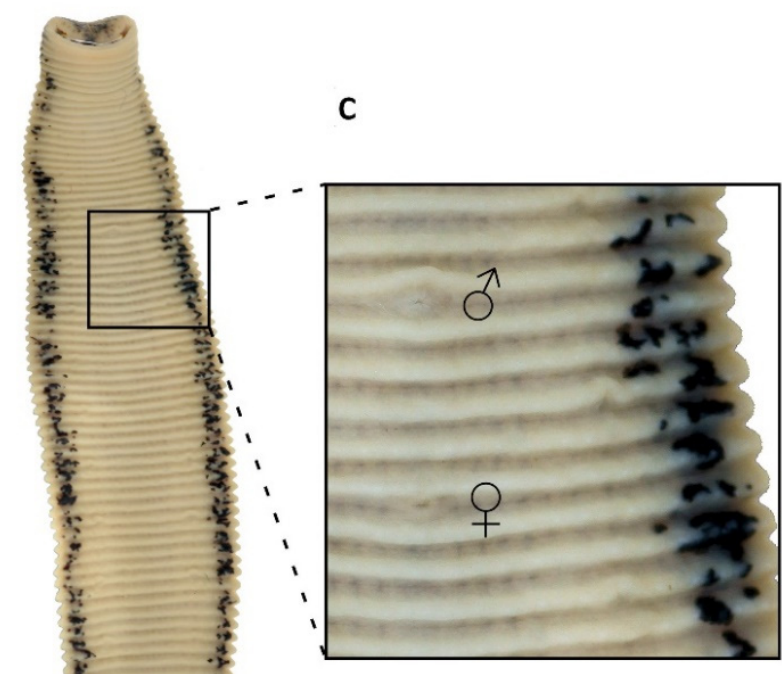

$1 \mathrm{~cm}$

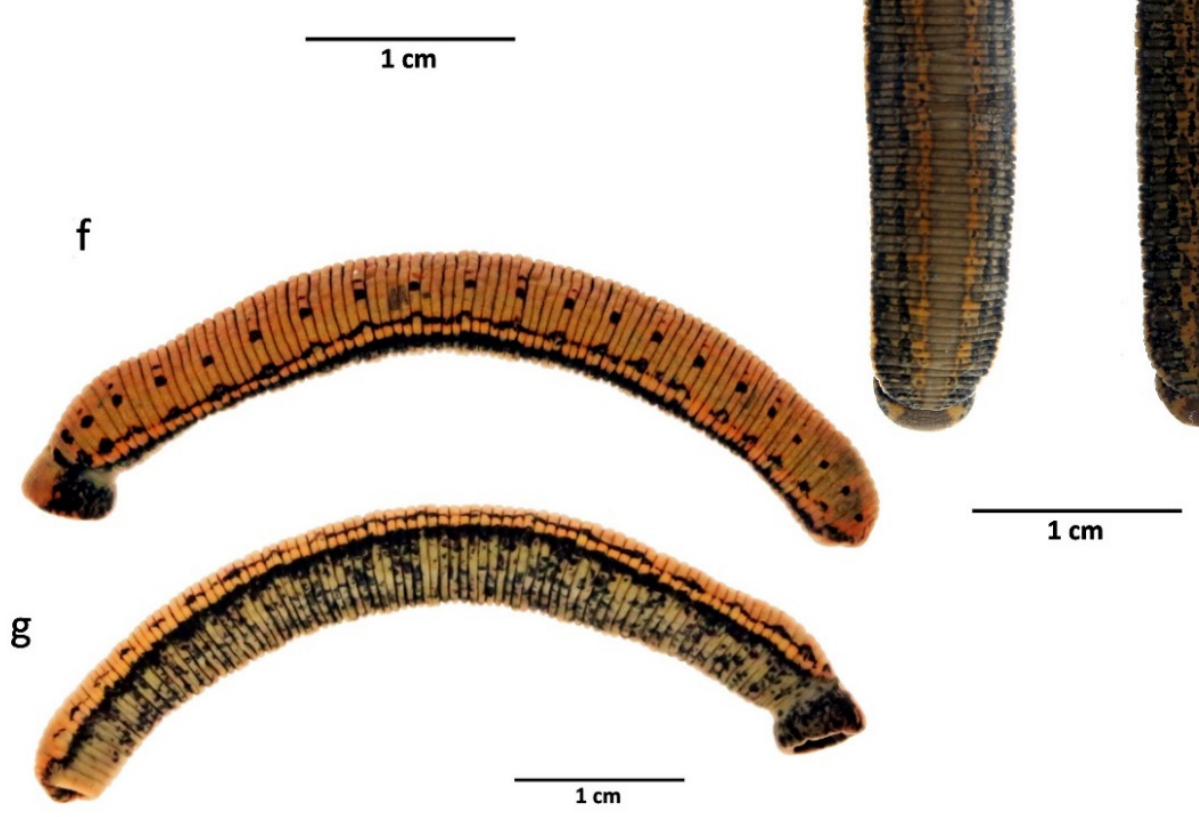

Figure 5. Iberian species of medicinal leeches treated in this work. (a,b) dorsal and ventral views of the holotype of Hirudo verbana bilineata ssp. nov; (c) detailed view of genital pores of the same; (d,e) Hirudo verbana "typical" from Galicia (NW Spain), dorsal view; (f,g) dorso-lateral and ventro-lateral views of Hirudo troctina from Asturias (N Spain).

Diagnosis: Medium-sized species, maximal length of about $80 \mathrm{~mm}$ including suckers; pigmentation of dorsum brownish to greenish with two pairs of distinct orange/reddish longitudinal lines or stripes, with or without small quadrangular or rounded dark spots on 
stripes; lateral margins with a longitudinal beige/light yellow stripe; venter unicoloured greenish to yellowish, without coloured markings and bounded by a pair of black ventrolateral stripes; jaws trignathous, monostichodont, papillated; no pharyngeal ridges terminating between jaws; epididymides medium-sized; vagina centrally swelled and curved.

Description: External characters: Length up to $80 \mathrm{~mm}$ after fixation, maximum body width $10.5 \mathrm{~mm}$, width of anterior sucker $5 \mathrm{~mm}$ (2.5-5), width of posterior sucker $7.5 \mathrm{~mm}$ (4-8); gonopores separated by five annuli, male pore in the furrow XI b5/b6, female pore in the furrow XII b5/b6; complete segment five-annulated (b1, b2, a2, b5, b6); body surface covered with numerous papillae; five pairs of eyes, on II, III, IV a1, V a1, and VI a2, in a horse-shoe arrangement; sulcus present as a narrow, distinct groove running from the crypt of the median dorsal jaw to the dorsal rim of the anterior sucker; dorsum brownish or greenish with two pairs of narrow orange or reddish longitudinal stripes (being sometimes both colour present on same individual: external line orange and inner one reddish) edged with black, with or without small quadrangular, rounded, or irregular dark spots on stripes (Figures $4 \mathrm{a}-\mathrm{c}$ and $5 \mathrm{a}, \mathrm{b}$ ); if present, marginal stripes yellow, edged with black line; venter unicoloured greenish, with two irregular black ventrolateral stripes (Figures 4a and 5b,c).

Mouthparts: Jaws trignathous, monostichodont, papillated.

Male reproductive system: Large and bulging atrium covered by a glandular layer and ubicated at ganglion in segment XI; penis sheath as long broad duct anteriorly bent and reaching ganglion in segment XII. Discoid and medium-sized epididymides, as tightly packed masses of ducts standing upright on either side of atrium and located between ganglia in segments XI and XII. Fusiform and well-developed ejaculatory bulbs and not larger than epididymides, the dorsocefalic faces of which they circle. Thin vasa deferentia running from epididymides to posterior end. Nine pairs of testisacs present; two anteriormost ones rounded, approximately 1.5 times larger than ovisacs and located posterior to ganglion in segment XIII (Figure 6).

a

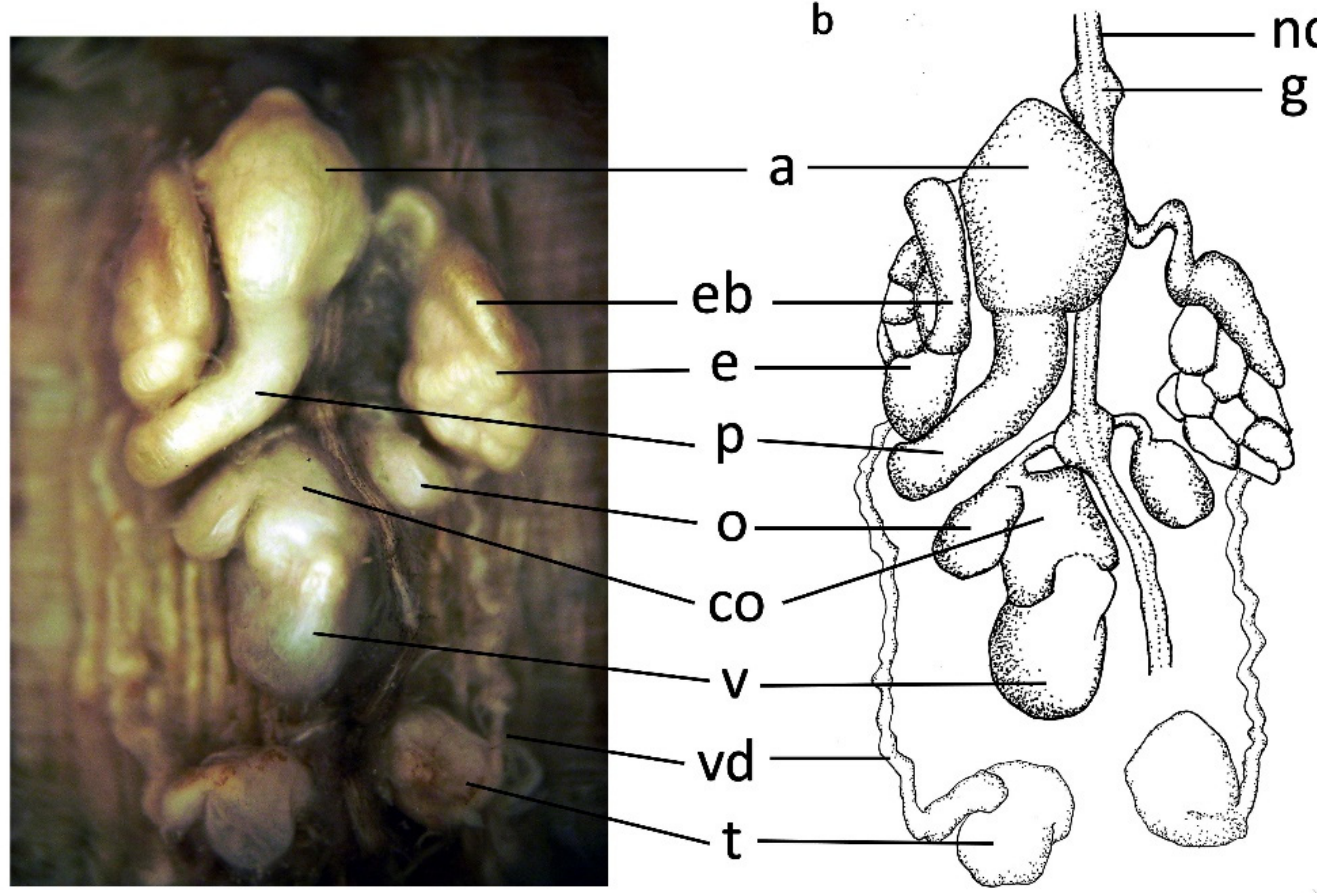

nc

Figure 6. Hirudo verbana bilineata ssp. nov. $(\mathbf{a}, \mathbf{b})$ dorsal view of reproductive system of nov. a, atrium, co, common oviduct, e, epididymis, eb, ejaculatory bulb, g, ganglion in segment XI, nc, ventral nerve cord, o, ovisac, $p$, penis sheath, $t$, testisac, v, vagina, vd, vas deferens. 
Female reproductive system: Vagina as upright, centrally swelled, curved tube entering directly in ventral body wall, posterior to ganglion in XII. Common oviduct reaches vagina subterminally at a small vaginal caecum. Common oviduct as thin duct with several loops and covered by a thick glandular layer bound to the cephalic face of vagina. Globular and small ovisacs. Whole female reproductive system located between ganglia XII and XIII (Figure 6).

Remarks: Hirudo verbana bilineata is very similar to other $H$. verbana in a number of external and internal characters; however, it can be easily distinguished from them using some manifest features. The pigmentation is the most helpful character in identifying these leeches, $H$. verbana bilineata differs from the remaining forms of $H$. verbana by bearing two thin, paired, and deep orange to reddish lines that run parallel on both sides of the dorsum along its whole length, whereas the other $H$. verbana morphs have broad and diffuse paramedian stripes which are pale orange in colour (this pattern is referred here as "typical"). The venter of all known forms of $H$. verbana, including $H$. verbana bilineata, is unicolored greenish to yellow, bounded by a pair of black ventrolateral stripes, while $H$. medicinalis and $H$. orientalis present a dark ventral pigmentation, varying from an irregular mesh-like pattern in the former to a more regular, with segmentally arranged pairs of light markings on a black background in $H$. orientalis. In northern Spain, H. verbana bilineata occurs sympatrically with $H$. troctina. However, these species tend to occupy different habitats (this statement is more detailed explored in the discussion below). Both species can be easily distinguished by the dorsal and ventrolateral colour patterns that are strictly different. Hirudo troctina has a distinctive pair of zigzag-shaped and black ventrolateral longitudinal stripes, which is absent in all other European Hirudo species. For the sake of completeness, an alternative and putative scenario has been assessed. This is that the new subspecies could be a hybrid of $H$. verbana and $H$. troctina. The first observation that rules out this "hybridization scenario" is the fact the two supposedly parent species exhibit different habitat preference and therefore they cannot interact under natural conditions (i.e., there is an ecological barrier between both species). We also addressed this scenario from a genetic point of view. If the hybridization occurred, $H$. verbana should have acted as a female (since all our putative hybrid specimens share the same mtDNA with $H$. verbana) and $H$. troctina as a male. Thus, the presumed hybrids would be the offspring of a female $H$. verbana and a male $H$. troctina. The analysis of a nuclear gene, which exhibits differences between $H$. verbana and H. troctina, should allow us to recover (in the supposed hybrids) the paternal (H. troctina) gene variant. Therefore, we sequenced the Internal Transcribed Spacer (ITS2) nuclear marker in four specimens of the $H$. verbana bilineat $a$ and compared them with 27 ITS2 sequences of $H$. verbana and one of H. troctina retrieved from Genbank [4]. This revealed that all $H$. verbana bilineata specimens belong to a single haplotype (GenBank acc. no. MW820085), which is also the most frequent haplotype found among $H$. verbana. The only found $H$. troctina ITS2 haplotype is easily set apart from the $H$. verbana haplotypes, as depicted by a Minimum Spanning Analysis implemented in PopART v. 1.7. [40] (Figure 7). Thus, from both an ecological and genetical point of view, the hybridization scenario is highly unlikely, and therefore, it can be objectively discarded. 


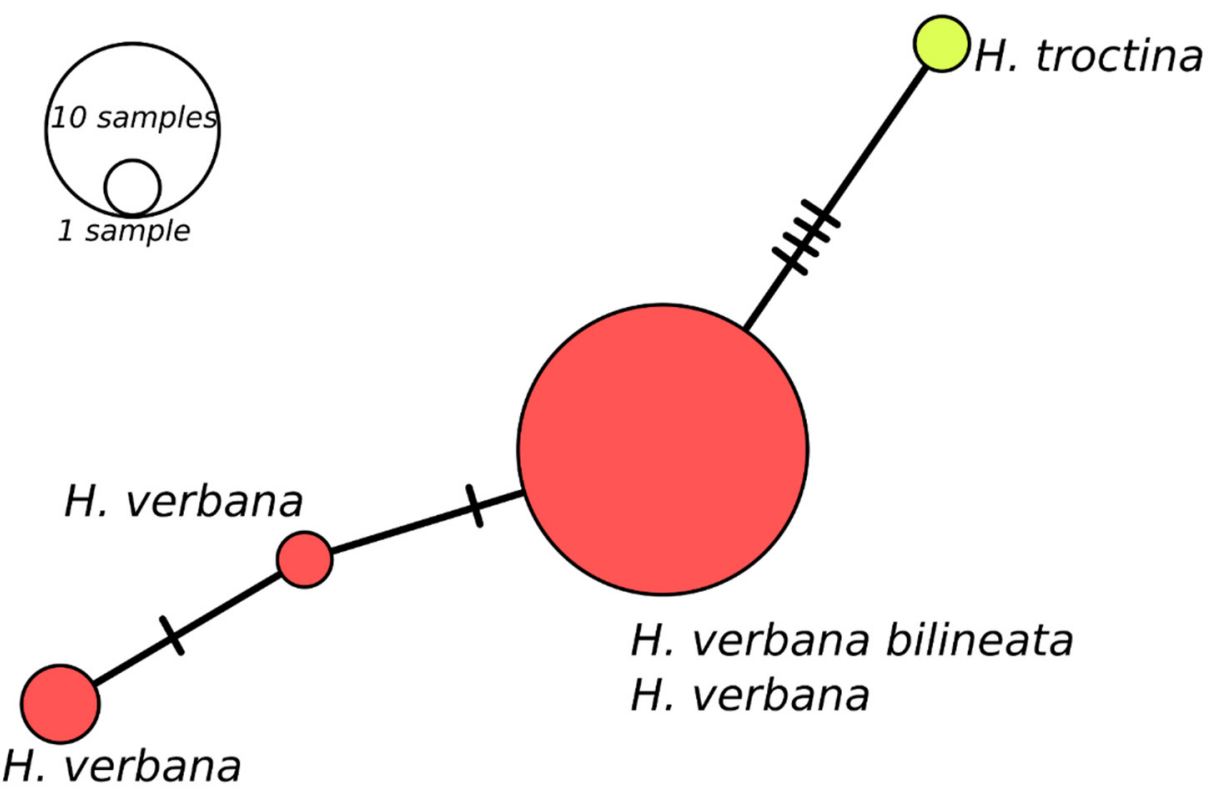

Figure 7. Minimum spanning network of Hirudo verbana and Hirudo troctina ITS2 haplotypes. The bars on branch length represent the number of substitutions.

Habitat and distribution: Hirudo verbana bilineata is only known from the standing waters of hills and mountain plains pools of the Basque Country and León (northern Spain) (Figures 1 and 8). Current populations of this new subspecies (Bikuña and Cueza) are located on an ecotone or "transition area" between the Atlantic Cornisa Cantábrica (Atlantic Eurosiberian Biogeographic Region) and the Mediterranean Valley of Ebro River (Mediterranean Biogeographic Region) (Figure 1). The examination of historical collections of the BOS Department (University of Oviedo) demonstrated that this subspecies was also present in several ponds from the Kuartango Valley (500-1000 m altitude, Basque Country, N Spain) until the 90s, when the leeches became extinct from the area [31]. No $H$. verbana specimens were found in the Collections of the MNCN, all Hirudo specimens belong to $H$. troctina. The latter species was also present in the BOS Collection from some mountain streams of Asturias (northern Spain) (Figure 5f,g). It is important to note that all examined specimens of $H$. troctina were collected from moving water bodies, such as rivers and streams, while all $H$. verbana specimens found came from habitats that are primarily standing waters, such as lakes and ponds.

This new subspecies was found in clear, still, lentic, or low-flowing waters of 0.1-1.5 m depth, as part of the Chara-Potamogeton community. Potamogeton sp. is a profusely branched, rhizomatous perennial with submerged filiform leaves (Figure 8c), which constitutes a sheltered three-dimensional habitat to a great number of associated animals. The Iberian green frog (Pelophylax perezi) and the Alpine newt (Ichthyosaura alpestris) were very common in the $H$. verbana bilineata habitat and both amphibians were observed acting as hosts of this new subspecies in nature. 

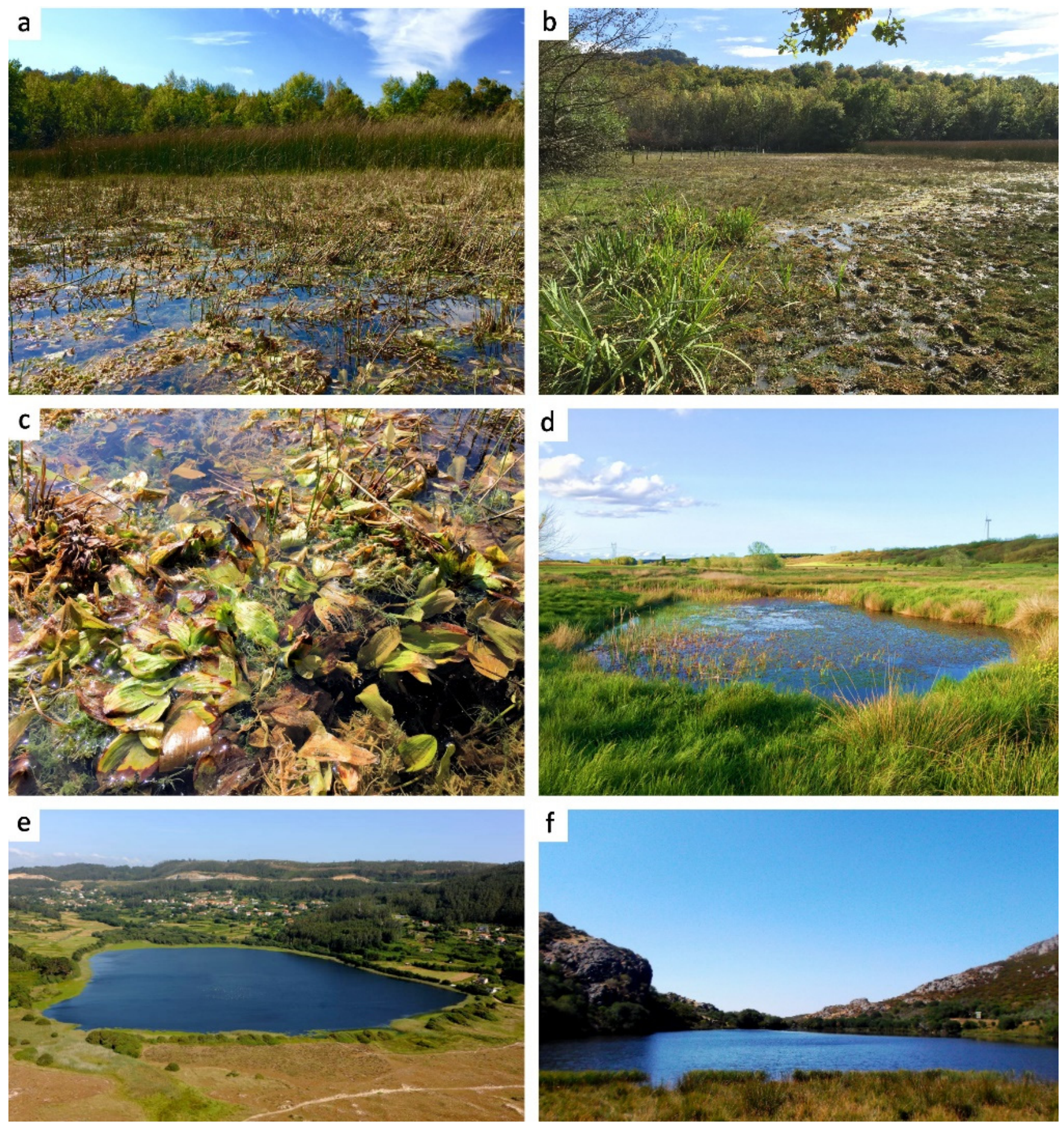

Figure 8. Habitats of Hirudo verbana in Spain. (a,b) Bikuña pond (Basque Country), type locality of H. verbana bilineata ssp. nov.; (c) detailed view of the same showing the Chara-Potamogeton association; (d) Cueza pond (León); (e) Doniños Lake (Galicia); (f) Ocelo lake (Galicia).

In relation to the physicochemical parameters, the Bikuña pond presents a marked seasonality. In the summer months it suffers from low-water but does not get completely dry. Its maximum depth does not exceed $1 \mathrm{~m}$. The water temperature varies from $4{ }^{\circ} \mathrm{C}$ in the winter months (never reaching the freezing point) to over $20^{\circ} \mathrm{C}$, reaching temperatures above $25^{\circ} \mathrm{C}$ on the hottest days of the summer. The $\mathrm{pH}$ through the whole annual cycle is always above 7 , normally varying in a range between 7.5 and 8.5 (Red de seguimiento del estado ecológico de los humedales interiores, Agencia Vasca del 
Agua [https:/ / www.uragentzia.euskadi.eus/red-de-seguimiento-del-estado-ecologicode-los-humedales-interiores-20162017/u81-0003771/es / ] accessed on 29 June 2020).

Hirudo verbana cf. verbana Carena, 1820 ("Iberian typical")

Examined material: Hirudo verbana "typical": Two specimens, Doniños lake, $4.5 \mathrm{~m}$ altitude, $42^{\circ} 29^{\prime} 31^{\prime \prime} \mathrm{N}, 8^{\circ} 18^{\prime} 44^{\prime \prime}$ W, A Coruña, Galicia, Spain; two specimens, Gándaras de Budiño lake, $20 \mathrm{~m}$ altitude, $42^{\circ} 06^{\prime} 43^{\prime \prime} \mathrm{N}, 8^{\circ} 37^{\prime} 48^{\prime \prime} \mathrm{W}$, Pontevedra, Galicia, Spain; one specimen, Water channel of Antela lake, Antela Valley, $610 \mathrm{~m}$ altitude, $42^{\circ} 05^{\prime} 24^{\prime \prime} \mathrm{N}, 7^{\circ} 45^{\prime} 00^{\prime \prime} \mathrm{W}$, Ourense, Galicia, Spain; four specimens, Xuño lake, $4 \mathrm{~m}$ altitude, $42^{\circ} 38^{\prime} 00^{\prime \prime} \mathrm{N}, 9^{\circ} 02^{\prime} 18^{\prime \prime} \mathrm{W}$, A Coruña, Galicia, Spain; three specimens, Ocelo lake, Pena Trevinca mountains, $1517 \mathrm{~m}$ altitude, $42^{\circ} 13^{\prime} 36^{\prime \prime}$ N, $6^{\circ} 52^{\prime} 22^{\prime \prime}$ W, Ourense, Galicia, Spain. For historical examined material see Table 3 .

Table 3. Summary of historical collection Hirudo specimens examined in this study.

\begin{tabular}{|c|c|c|c|c|c|}
\hline Species & No. of Specimens & Habitat & Locality & Coll. Date & Reg. Number \\
\hline $\begin{array}{l}\text { Hirudo troctina } \\
\text { Johnson, } 1816\end{array}$ & 6 & Niebla stream & $\begin{array}{l}\text { Plasencia, Cáceres, } \\
\text { Extremadura }\end{array}$ & May 1944 & MNCN 16.02/85 \\
\hline $\begin{array}{l}\text { Hirudo troctina } \\
\text { Johnson, } 1816\end{array}$ & 1 & Alagón river & $\begin{array}{l}\text { Coria, Cáceres, } \\
\text { Extremadura }\end{array}$ & May 1944 & MNCN 16.02/84 \\
\hline $\begin{array}{l}\text { Hirudo troctina } \\
\text { Johnson, } 1816\end{array}$ & 3 & Tiétar river & $\begin{array}{l}\text { Casavieja, Ávila, } \\
\text { Castilla y León }\end{array}$ & May 1932 & MNCN 16.02/81 \\
\hline $\begin{array}{l}\text { Hirudo troctina } \\
\text { Johnson, } 1816\end{array}$ & 1 & Jerte river & $\begin{array}{l}\text { Plasencia, Cáceres, } \\
\text { Extremadura }\end{array}$ & May 1944 & MNCN 16.02/71 \\
\hline $\begin{array}{l}\text { Hirudo troctina } \\
\text { Johnson, } 1816\end{array}$ & 1 & Arrago river & $\begin{array}{l}\text { Moraleja, Cáceres, } \\
\text { Extremadura }\end{array}$ & June 1944 & MNCN 16.02/70 \\
\hline $\begin{array}{l}\text { Hirudo troctina } \\
\text { Johnson, } 1816\end{array}$ & 1 & Panes stream & $\begin{array}{l}\text { Panes, Peñamellera } \\
\text { Baja, Asturias }\end{array}$ & August 1992 & BOS Collection \\
\hline $\begin{array}{l}\text { Hirudo troctina } \\
\text { Johnson, } 1816\end{array}$ & 1 & Panes stream & $\begin{array}{l}\text { Panes, Peñamellera } \\
\text { Baja, Asturias }\end{array}$ & August 1992 & Utevsky S. Collection \\
\hline $\begin{array}{l}\text { Hirudo troctina } \\
\text { Johnson, } 1816\end{array}$ & 1 & Bedón river & Naves, Llanes, Asturias & 1980s & BOS Collection \\
\hline $\begin{array}{l}\text { Hirudo troctina } \\
\text { Johnson, } 1817\end{array}$ & 1 & Pas river & $\begin{array}{l}\text { Vioño de Piélagos, } \\
\text { Piélagos, Cantabria }\end{array}$ & 1980s & BOS Collection \\
\hline $\begin{array}{l}\text { Hirudo verbana cf. } \\
\text { verbana Carena, } 1820\end{array}$ & 1 & $\begin{array}{l}\text { Kuartango Valley } \\
\text { ponds }\end{array}$ & $\begin{array}{c}\text { Zuazo de Cuartango, } \\
\text { Álava, Basque Country }\end{array}$ & 1980-1990 & Utevsky S. Collection \\
\hline $\begin{array}{l}\text { Hirudo verbana cf. } \\
\text { verbana Carena, } 1820\end{array}$ & 20 & $\begin{array}{l}\text { Kuartango Valley } \\
\text { ponds }\end{array}$ & $\begin{array}{l}\text { Zuazo de Cuartango, } \\
\text { Álava, Basque Country }\end{array}$ & $1980-1990$ & BOS Collection \\
\hline
\end{tabular}

Diagnosis: Medium-sized species, maximal length of about $70 \mathrm{~mm}$ including suckers; maximum body width $9 \mathrm{~mm}$; pigmentation of dorsum greenish with an orange-pigmented longitudinal reticulum; lateral margins with a longitudinal beige to yellow stripe; venter unicoloured greenish to yellowish, with no (or very few) dark spots and a pair of black marginal stripes (Figure 5d,e); jaws trignathous, monostichodont, papillated; no pharyngeal ridges terminating between jaws; epididymides medium-sized; vagina centrally swelled and curved.

Habitat and distribution: Hirudo verbana cf. verbana is only known from the lakes, ponds, and pools of Galicia and the Basque Country from 4 to $1517 \mathrm{~m}$ of altitude (NW to N Spain) (Figures 1 and 8; Table 3). However, in our sampling, this subspecies was only found in Galicia. The Basque Country populations registered from the historical collections are most likely extinct today [31].

Hirudo troctina Johnson, 1816

Diagnosis: Small to medium-sized species, medium length of about $50 \mathrm{~mm}$ including suckers; pigmentation of dorsum greenish to greyish with four or six dorsal metameric black dots; lateral margins with a longitudinal orange stripe; venter unicoloured greenish to yellowish, with dark spots and a pair of black marginal stripes arranged in zigzag (Figure 5f,g); jaws trignathous, monostichodont, papillated; with six muscular ridges 
fusing in pairs to form three, each of which terminates at the base of a jaw; epididymides very large; broad, elongate, and centrally swelled vagina and tapering at both ends.

Examined material: See Table 3.

Habitat and distribution: High to medium flow rivers and streams from southern, central and northern Spain. Our last confirmed historical record of the species dates back 1992 from northern Spain (Table 3). No specimens were found in our sampling from 2015 to 2017.

\section{Discussion}

Medicinal leeches were historically popularised for their utility in bloodletting (phlebotomy) in the 18th and 19th centuries. They have experienced a recent prominence again in post-operative treatments for flap and replantation surgeries, and in terms of characterization and isolation of salivary anticoagulants $[1,6,24]$. Medicinal leeches were raised for commercial purposes in ponds in the 18th and 19th centuries from several European countries, including Spain and its neighbours Portugal and France. Millions of these leeches were used in hospitals, barber shops, and pharmacies of the time $[25,26]$. There was a huge trade in medicinal leeches, and local production was commonly supplemented by importations from abroad [26,27]. Only in Spain, the import/export traffic by maritime trade in the mid-19th century, accounted for between 10,000 and 1 million individuals per year [26]. This triggered a massive over-exploitation of natural populations of medicinal leeches, causing these species across some areas, like northern Spain, to became scarce since the mid-19th century $[13,15]$. Despite their great past and present importance in medicine and pharmacology, our knowledge of medicinal leech diversity, distribution, and zoogeography is still incomplete. A clear example of this is represented by the Iberian medicinal leeches, which have been studied insufficiently and unsystematically. Here, we report for the first time the occurrence of $H$. verbana from the Iberian Peninsula, constituting its westernmost distribution to date.

Iberian populations correspond to two different morphotypes, which are also supported by molecular data. It is widely accepted that external pigmentation is not only one of the most useful features to distinguish leech species, but also arguably the best character to diagnose species within the genus Hirudo [1,3,6,24]. Apart from the smaller size of the Iberian H. verbana specimens with "typical" colour (max. $70 \mathrm{~mm}$ long $/ 9 \mathrm{~mm}$ width) in relation to the other European clades (max. 100-140 mm/10-12 mm width) [1,3,6,24], we did not find other clear enough morphological differences and thus we do not formally describe them as a subspecies in the present study. However, we found genetic differentiation in the analysed mitochondrial markers and therefore, we referred to it as H. verbana cf. verbana. These findings suggest that the genetic diversity within $H$. verbana is considerably higher than it was accepted before. Thus, each of the four provided clades within H. verbana may represent a subspecific status. This hypothesis should be investigated further based on examination of additional material and genetic markers. The taxonomic rank of subspecies remains highly contentious, largely because traditional subspecies boundaries have sometimes been contradicted by molecular data [28]. However, our results demonstrate a high level of congruence between "morphosubspecies" and molecular phylogenetic data. The distribution range of Iberian Hirudo morphotypes is divided into two well-delimited geographical groups with some morphological differences. Hirudo verbana bilineata inhabits the mountain small ponds or pools (of more than $800 \mathrm{~m}$ high) of the Cantabrian Mountains ("Cordillera Cantábrica" in Spanish) that stretch for over $300 \mathrm{~km}$ across northern Spain (Figures 1 and $8 \mathrm{a}-\mathrm{c}$ ). Otherwise, H. verbana "typical" was found from large lakes at lower altitude from the Galician Massif in Galicia (NW Spain) (Figures 1 and 8e,f). Using an integrative approach (a combination of morphology and molecular data), we found that the two geographical groups should be considered as two separate taxa. Accordingly, we formally describe the new subspecies $H$. verbana bilineata. Morphological analyses support the differentiation of this new subspecies from the other Iberian morphotype and the remaining Iberian phylogroups of $H$. verbana. There are strong diagnostic characters to 
differentiate them based upon the colour pattern and size. In addition to morphology and genetics, slightly divergent habitat preferences and the disjunctive distribution of the two subspecies also support the recognition of the new taxa. Iberian $H$. verbana populations (i.e., the Iberian phylogroup) constitute an important component in the evolutionary legacy of the European medicinal leeches, and thus, the populations of $H$. verbana bilineata and "typical" H. verbana, are here considered as Evolutionarily Significant Units (ESUs). Accordingly, they should be treated as distinct and as a priority for purposes of conservation. This is a pivotal point, because Iberian medicinal leech populations have been declining in recent decades as both direct and indirect results of human activity $[13,15,17,31]$.

Some northern Iberian literature records of $\mathrm{H}$. medicinalis and H. officinalis may actually refer to this new subspecies $[18,29]$. However, most of them do not provide information about their colour patterns nor photographs or drawings of the specimens, so they cannot be formally confirmed. As an exception, Laborda [30] in his handbook of the fauna of León presents a photograph of a live specimen of presumed $H$. medicinalis showing the typical bilineated pattern of $H$. verbana bilineata [30]. In the same way, the illustrated specimens reported as H. medicinalis by Ocharan [31] from Kuartango (Alava, Basque Country) and by García-Mas and Muñoz [15], are indeed H. verbana of the "typical" pattern [15,31]. Similarly, it is likely that Portuguese medicinal leeches also belong to $H$. verbana, since they were traditionally marketed as "green leeches" or "Lisbon brand" (common names attributed to H. verbana) [28]. Conversely, the leeches from northern Europe (H. medicinalis) were historically known as "Black leeches" or "Hamburg brand" [32]. Ayres and ComesañaIglesias [16] have reported H. medicinalis as being a parasite on the Iberian brown frog Rana iberica. Although it is difficult to ascertain from the non-diagnostic photograph provided, the location where they found this medicinal leech (i.e., a small stream in Barranqueira de Casariños, Pontevedra, Galicia) falls within the distribution area of the "typical" morph of $H$. verbana herein reported. Therefore, these leeches may be referred to as H. verbana. On the contrary, in other records of amphibian predation by H. medicinalis from northern Spain [33], it is evident (thanks to the provided images) that the species was misidentified and does not correspond to any member of the genus Hirudo, but most likely to the horse-leech Haemopis sanguisuga.

Blanchard [18] noted that $H$. troctina was not confined to southern Spain as previously considered. Almost 100 years later, Fernández-Bernaldo-de-Quirós [34] reported the species from two Asturian rivers near their mouths in the Cantabrian sea (between 0.5 and $10 \mathrm{~m}$ altitude) [34]. The conducted revision, based upon historical collections (Table 3), confirms the occurrence of this species in northern Spain, specifically from A Coruña and Lugo and as far as $43^{\circ}$ lat. $\mathrm{N}$ (Asturias). Furthermore, our results have shown that $H$. troctina differs in its habitats from $H$. verbana, preferring moving bodies of water to lentic ecosystems. This statement is also supported by bibliographic data, since, to our knowledge, all the Iberian records come from rivers or streams (see [18-20,34,35]).

Furthermore, there are no reports of co-occurrence of these two species in the same water body, so it is unlikely that both species can outcompete each other. Taking into account the new provided information on the distribution and morphological diversity of $H$. verbana in Iberia, the previously reported Hirudo spp. records should be taken with caution until new evidence can confirm that these populations are still extant.

It is very likely that before Pleistocenic glaciations $H$. verbana occurred throughout the Western Palaearctic. The major clades of H. verbana (the Western and Eastern phylogroups and the Iberian superclade), which do not overlap in their geographical distribution, support the hypothesis of a distinct postglacial colonization process from Mediterranean peninsulas [4]. The Eastern phylogroup recolonized vast territories of the eastern steppe and arid landscapes, while Western and Iberian phylogroups are restricted to the Apennine and Iberian peninsulas and adjacent areas. Moreover, the geographic structuring of the two Iberian lineages of medicinal leeches (H. verbana bilineata in the upper reaches of the Duero, Ebro and northern rivers catchment and H. verbana "typical" in the Miño-Sil watershed) indicates survival in at least two different Pleistocene glacial refugia. Therefore, the Iberian 
Peninsula is regarded more likely as a cradle for freshwater endemisms rather than a single refugium, as has been previously suggested by Gómez and Lunt [11]. Certainly, Iberian $H$. verbana ssp. distribution patterns contribute to a better understanding of the internal complexity of the Iberian Peninsula as a source of glacial relics/endemic taxa, harbouring populations with a high degree of genetic structure that began to settle throughout the Pleistocene.

\section{Conclusions}

Iberian Hirudo populations are declining in recent decades as both a direct and indirect result of human activity. We have here described $H$. verbana bilineata, which was only found in two localities in low numbers. Thus, this new subspecies, as well as the typical morph of $H$. verbana, can be considered as locally rare taxa, being also consistent with the definition of an Evolutionarily Significant Unit. Rarity of species is usually explained by a combination of extensive versus restricted geographic range, broad versus narrow habitat tolerance and large versus small population size. Iberian $H$. verbana populations combine restricted geographic ranges with narrow habitat and small population size, making them vulnerable to extinction. Therefore, there is an urgent need to assess in detail the conservation status and to initiate conservation measures for this endemic subspecies and its congeners, in order to reverse their decline and recover them.

Despite the long history of studies about the taxonomy and phylogeny of medicinal leeches, our knowledge is still incomplete. Undoubtedly, further investigations involving testing of nuclear genetic markers and morphological variation in "Iberian typical" $H$. verbana is required. Application of scanning electron microscopy and molecular tools may shed light on the evolutionary history of medicinal leech populations from other Mediterranean peninsulas and the Western European countries, which may preserve unrecognized diversity of Hirudo species. The broader view is that $H$. verbana subspecies/phylogroups can provide an effective short-cut for estimating patterns of intraspecific genetic diversity, thus constituting a useful tool for the study of evolutionary divergence and conservation in medicinal leeches in Europe.

Author Contributions: Conceptualization, A.A., V.S., and S.U.; methodology, A.A., V.S., R.C., O.P.P., L.O.P., and S.U.; formal analysis, A.A., V.S., R.C., O.P.P., L.O.P., and S.U.; investigation, A.A., V.S., R.C., O.P.P., L.O.P., and S.U.; resources, A.A. and R.C.; data curation, A.A., V.S., R.C., O.P.P., L.O.P. and S.U.; writing-original draft preparation, A.A.; writing-review and editing, A.A., V.S., R.C., O.P.P., L.O.P., and S.U.; supervision, A.A.; project administration, A.A.; funding acquisition, A.A. All authors have read and agreed to the published version of the manuscript.

Funding: This research was funded by the project FUO-20-278 (Fundación Universidad de OviedoDirección General de Medio Natural y Planificación Rural (Consejería de Medio Rural y Cohesión Territorial del Gobierno del Principado de Asturias)). The APC was funded by the project FUO-20-278 (Fundación Universidad de Oviedo-Dirección General de Medio Natural y Planificación Rural (Consejería de Medio Rural y Cohesión Territorial del Gobierno del Principado de Asturias)).

Institutional Review Board Statement: Not applicable.

Informed Consent Statement: Not applicable.

Data Availability Statement: All data generated or analysed during this study are included in this published article. Type material is deposited in the Museo Nacional de Ciencias Naturales (MNCN) of Madrid, Spain. The new subspecies is deposited in ZooBank with accession number urn:lsid:zoobank.org:act:7A75F602-2BF7-4686-BF9B-C83CBCDBC94C. All sequences were deposited in GenBank (https: / www.ncbi.nlm.nih.gov/nuccore/ accessed on 17 June 2020) with accession number from MT797288 to MT797292 (COI) and from MT796846 to MT796850 (12S).

Acknowledgments: We specially thank Javier Sánchez (MNCN) for his curatorial help and Nuria Anadón (University of Oviedo) and Carlos Nores (University of Oviedo) for providing key references. We are also grateful to Francisco J. Ocharan (University of Oviedo), Mercedes Herrera (University of the Basque Country UPV/EHU), Iñigo Zuberogoitia (University of the Basque Country UPV/EHU), Luis Mario Arce, Miguel González-Menéndez, Rafael García and Jesús Arias for their help in locating 
specimens or in the field sampling. We are deeply grateful to three anonymous reviewers and Michael Tessler for helpful comments and suggestions. We thank Local Government Administrations of Principado de Asturias (Dirección General de Medio Natural y Planificación Rural), Xunta de Galicia, Castilla y León and Gobierno Vasco for help and for providing collecting permits.

Conflicts of Interest: The authors declare no conflict of interest.

\section{Appendix A}

Table A1. Analysed samples with accession numbers, codes, haplotypes and reference.

\begin{tabular}{|c|c|c|c|c|}
\hline Species/Provenance & GenBank Acc. No COI & GenBank Acc. No 12S & Haplotype & Reference \\
\hline Limnatis cf. nilotica & AY763152 & AY763161 & $\mathrm{H} 27$ & $\begin{array}{l}\text { (Trontelj \& } \\
\text { Utevsky [1]) }\end{array}$ \\
\hline \multicolumn{5}{|l|}{ Hirudo medicinalis Linnaeus, 1758} \\
\hline Gorelaya Dolina, Kharkiv Region, UA & AY763148 & AY763156 & $\mathrm{H} 3$ & $\begin{array}{l}\text { (Trontelj \& } \\
\text { Utevsky [1]) }\end{array}$ \\
\hline Saale River, Rotherburg, Halle, DE & AY763148 & AY763157 & $\mathrm{H} 4$ & $\begin{array}{l}\text { (Trontelj \& } \\
\text { Utevsky [1]) }\end{array}$ \\
\hline Podvinci pond, Ptuj, SI & AY763149 & AY763158 & H5 & $\begin{array}{l}\text { (Trontelj \& } \\
\text { Utevsky [1]) }\end{array}$ \\
\hline Petajnci gravel pit; Murska Sobota, SI & AY763149 & AY763159 & H6 & $\begin{array}{l}\text { (Trontelj \& } \\
\text { Utevsky [1]) }\end{array}$ \\
\hline \multicolumn{5}{|l|}{ Hirudo verbana Carena, 1820} \\
\hline Lecce, IT & AY763150 & AY763160 & H7 & $\begin{array}{c}\text { (Trontelj \& } \\
\text { Utevsky [1])) }\end{array}$ \\
\hline Lake Ohrid, Ohrid, MK & AY763150 & AY763160 & $\mathrm{H} 7$ & $\begin{array}{l}\text { (Trontelj \& } \\
\text { Utevsky [1]) }\end{array}$ \\
\hline Pond Globobaj near Povir, Seqana, SI & AY763151 & AY763160 & $\mathrm{H} 8$ & $\begin{array}{l}\text { (Trontelj \& } \\
\text { Utevsky [1]) }\end{array}$ \\
\hline PA55, Island Pag, HR & EF446690 & AY763160 & $\mathrm{H} 8$ & (Siddall et al. [5]) \\
\hline PA54, Island Pag, HR & EF446691 & AY763160 & $\mathrm{H} 8$ & (Siddall et al. [5]) \\
\hline OH33, Lake Ohrid, MK & EF446693 & AY763160 & $\mathrm{H} 7$ & (Siddall et al. [5]) \\
\hline OH31, Lake Ohrid, MK & EF446694 & AY763160 & $\mathrm{H} 7$ & (Siddall et al. [5]) \\
\hline KR41, Gabrovica, SW, Sl & EF446695 & AY763160 & H8 & (Siddall et al. [5]) \\
\hline KR40, Gabrovica, SW, Sl & EF446696 & AY763160 & $\mathrm{H} 8$ & (Siddall et al. [5]) \\
\hline X1, Lecce, S IT & EF446698 & AY763160 & $\mathrm{H} 7$ & (Siddall et al. [5]) \\
\hline KA49 Povir, SW SI & EF446699 & AY763160 & $\mathrm{H} 8$ & (Siddall et al. [5]) \\
\hline KA47 Povir, SW SI & EF446700 & AY763160 & $\mathrm{H} 8$ & (Siddall et al. [5]) \\
\hline KA46 Povir, SW SI & EF446701 & AY763160 & $\mathrm{H} 8$ & (Siddall et al. [5]) \\
\hline Kharkiv Reg., Horila Dolyna, NE, UA & JN083793 & JN104650 & H12 & (Siddall et al. [5]) \\
\hline Berezivka, SW, UA & JN083793 & JN104650 & $\mathrm{H} 12$ & (Siddall et al. [5]) \\
\hline Karateri, UZ & JN083793 & JN104652 & H13 & (Siddall et al. [5]) \\
\hline Kokhany, S, UA & JN083793 & JN104655 & $\mathrm{H} 12$ & (Siddall et al. [5]) \\
\hline Krasnodar, RU & JN083793 & JN104649 & $\mathrm{H} 12$ & $\begin{array}{l}\text { (Trontelj \& } \\
\text { Utevsky [4]) }\end{array}$ \\
\hline Severynivka, SW, UA & JN083793 & JN104650 & $\mathrm{H} 12$ & $\begin{array}{l}\text { (Trontelj \& } \\
\text { Utevsky [4]) }\end{array}$ \\
\hline Stavropol, RU & JN083793 & JN104650 & H12 & $\begin{array}{c}\text { (Trontelj \& } \\
\text { Utevsky [4]) }\end{array}$ \\
\hline Vilkove, SW, UA & JN083793 & JN104649 & $\mathrm{H} 12$ & $\begin{array}{l}\text { (Trontelj \& } \\
\text { Utevsky [4]) }\end{array}$ \\
\hline CRIMEEA. UA & JN083794 & JN104654 & H14 & $\begin{array}{l}\text { (Trontelj \& } \\
\text { Utevsky [4]) }\end{array}$ \\
\hline
\end{tabular}


Table A1. Cont.

\begin{tabular}{|c|c|c|c|c|}
\hline Species/Provenance & GenBank Acc. No COI & GenBank Acc. No 12S & Haplotype & Reference \\
\hline Berezivka, SW, UA & JN083795 & JN104650 & H15 & $\begin{array}{l}\text { (Trontelj \& } \\
\text { Utevsky [4]) }\end{array}$ \\
\hline Shaby, SW, UA & JN083795 & JN104649 & H15 & $\begin{array}{l}\text { (Trontelj \& } \\
\text { Utevsky [4]) }\end{array}$ \\
\hline Mayaky, Odessa Region, SW, UA & JN083796 & JN104653 & H16 & $\begin{array}{l}\text { (Trontelj \& } \\
\text { Utevsky [4]) }\end{array}$ \\
\hline Severynivka, SW, UA & JN083798 & JN104651 & H17 & $\begin{array}{l}\text { (Trontelj \& } \\
\text { Utevsky [4]) }\end{array}$ \\
\hline Izmir, TR & JN083800 & JN104649 & $\mathrm{H} 18$ & $\begin{array}{l}\text { (Trontelj \& } \\
\text { Utevsky [4]) }\end{array}$ \\
\hline North_TR & JN083800 & JN104649 & $\mathrm{H} 18$ & $\begin{array}{l}\text { (Trontelj \& } \\
\text { Utevsky [4]) }\end{array}$ \\
\hline Izmir, TR & JN083801 & JN104649 & H19 & $\begin{array}{l}\text { (Trontelj \& } \\
\text { Utevsky [4]) }\end{array}$ \\
\hline HV11, Izmir, TR & JN083802 & JN104649 & $\mathrm{H} 20$ & $\begin{array}{l}\text { (Trontelj \& } \\
\text { Utevsky [4]) }\end{array}$ \\
\hline HV12, Izmir, TR & JN083803 & JN104649 & $\mathrm{H} 21$ & $\begin{array}{l}\text { (Trontelj \& } \\
\text { Utevsky [4]) }\end{array}$ \\
\hline HV13, Izmir, TR & JN083804 & JN104649 & $\mathrm{H} 22$ & $\begin{array}{l}\text { (Trontelj \& } \\
\text { Utevsky [4]) }\end{array}$ \\
\hline HV14, Stavropol, RU & JN104641 & JN104650 & $\mathrm{H} 23$ & $\begin{array}{c}\text { (Trontelj \& } \\
\text { Utevsky [4]) }\end{array}$ \\
\hline HV15, Berezivka, SW, UA & JN104642 & JN104650 & $\mathrm{H} 24$ & $\begin{array}{l}\text { (Trontelj \& } \\
\text { Utevsky [4]) }\end{array}$ \\
\hline HV17, MalaK, S, UA & JN104644 & JN104649 & $\mathrm{H} 25$ & $\begin{array}{l}\text { (Trontelj \& } \\
\text { Utevsky [4]) }\end{array}$ \\
\hline $\begin{array}{l}\quad \text { ANN003, Bikuña pond, } \\
\text { Bikuña, Cuadrilla de Salvatierra, Álava, } \\
\text { Basque } \\
\text { Country, SP }\end{array}$ & MT797288 & MT796846 & $\mathrm{H} 1$ & Present study \\
\hline $\begin{array}{l}\text { ANN004, Bikuña pond, Bikuña, Cuadrilla } \\
\text { de Salvatierra, Álava, Basque Country, SP }\end{array}$ & MT797288 & MT796846 & $\mathrm{H} 1$ & Present study \\
\hline $\begin{array}{l}\text { ANN005, Bikuña pond, Bikuña, Cuadrilla } \\
\text { de Salvatierra, Álava, Basque Country, SP }\end{array}$ & MT797288 & MT796846 & $\mathrm{H} 1$ & Present study \\
\hline $\begin{array}{l}\text { ANN006, Bikuña pond, Bikuña, Cuadrilla } \\
\text { de Salvatierra, Álava, Basque Country, SP }\end{array}$ & MT797288 & MT796846 & $\mathrm{H} 1$ & Present study \\
\hline ANN007, León, Cueza, Castilla y León, SP & MT797289 & MT796847 & $\mathrm{H} 1$ & Present study \\
\hline $\begin{array}{l}\text { ANN008, Galicia BUD 3, Gándaras de } \\
\text { Budiño pond Pontevedra, Galicia, SP }\end{array}$ & MT797290 & MT796848 & $\mathrm{H} 2$ & Present study \\
\hline $\begin{array}{l}\text { ANN009, Galicia BUD } 4 \text { Gándaras de } \\
\text { Budiño pond Pontevedra, Galicia, SP }\end{array}$ & MT797290 & MT796848 & $\mathrm{H} 2$ & Present study \\
\hline $\begin{array}{l}\text { ANN010, Galicia DON } 3 \text { Doniños Lake, A } \\
\text { Coruña, Galicia, SP }\end{array}$ & MT797291 & MT796849 & $\mathrm{H} 2$ & Present study \\
\hline $\begin{array}{l}\text { ANN011, Galicia DON } 4 \text { Doniños Lake, A } \\
\text { Coruña, Galicia, SP }\end{array}$ & MT797291 & MT796849 & $\mathrm{H} 2$ & Present study \\
\hline ANN012, Galicia OCE 2 Orense, Galicia, SP & MT797292 & MT796850 & $\mathrm{H} 2$ & Present study \\
\hline \multicolumn{5}{|l|}{ Hirudo nipponia Whitman, 1886} \\
\hline Leech farm Hans Biomed, KR & AY763153 & AY763162 & H9 & $\begin{array}{l}\text { (Trontelj \& } \\
\text { Utevsky [1]) }\end{array}$ \\
\hline \multicolumn{5}{|l|}{ Hirudo orientalis Utevsky \& Trontelj, 2005} \\
\hline Unknown locality in Azerbaijan, AZ & AY763154 & AY763163 & $\mathrm{H} 10$ & $\begin{array}{l}\text { (Trontelj \& } \\
\text { Utevsky [1]) }\end{array}$ \\
\hline Agdam District, AZ & AY763154 & AY768704 & H10 & $\begin{array}{l}\text { (Trontelj \& } \\
\text { Utevsky [1]) }\end{array}$ \\
\hline
\end{tabular}


Table A1. Cont.

\begin{tabular}{lcccc}
\hline \multicolumn{1}{c}{ Species/Provenance } & GenBank Acc. No COI & GenBank Acc. No 12S & Haplotype & Reference \\
\hline Hirudo troctina Johnson, 1816 & & & & \\
\hline Bazaar in Marrakech, MA & AY763155 & AY763164 & H11 & (Trontelj \& \\
Utevsky [1]) & & & \\
\hline $\begin{array}{l}\text { Hirudo sulukii Saglam, Saunders, Lang and } \\
\text { Shain 2016 }\end{array}$ & & & & \\
\hline HS1, Kara Lake, Adiyaman, TR & KU216239 & KU216262 & H26 & (Saglam et al. [7]) \\
\hline
\end{tabular}

\section{References}

1. Trontelj, P.; Utevsky, S.Y. Celebrity with a neglected taxonomy: Molecular systematics of the medicinal leech (genus Hirudo). Mol. Phylogenet. Evol. 2005, 34, 616-624. [CrossRef]

2. Nesemann, H.; Neubert, E. Annelida, Clitellata: Branchiobdellida, Acanthobdellea, Hirudinea. In Süßwasserfauna von Mitteleuropa; Schwoerbel, J., Zwick, P., Eds.; Spektrum Akademischer Verlag: Heidelberg, Germany, 1999; pp. 1-62.

3. Hechtel, F.O.P.; Sawyer, R.T. Toward a taxonomic revision of the medicinal leech Hirudo medicinalis Linnaeus, 1758 (Hirudinea: Hirudinidae): Re-description of Hirudo troctina Johnston, 1816 from North Africa. J. Nat. Hist. 2002, 36, 1269-1289. [CrossRef]

4. Trontelj, P.; Utevsky, S.Y. Phylogeny and phylogeography of medicinal leeches (genus Hirudo): Fast dispersal and shallow genetic structure. Mol. Phylogenet. Evol. 2012, 63, 475-485. [CrossRef]

5. Siddall, M.E.; Trontelj, P.; Utevsky, S.Y.; Nkamany, M.; Macdonald, K.S. Diverse molecular data demonstrate that commercially available medicinal leeches are not Hirudo medicinalis. Proc. R. Soc. B 2007, 274, 1481-1487. [CrossRef] [PubMed]

6. Utevsky, S.Y.; Zagmajster, M.; Atemasov, A.; Zinenko, O.; Utevska, O.M.; Utevsky, A.Y.; Trontelj, P. Distribution and status of medicinal leeches (genus Hirudo) in the Western Palaearctic: Anthropogenic, ecological, or historical effects? Aquat. Conserv. 2010, 20, 198-210. [CrossRef]

7. Sağlam, N.; Saunders, R.; Lang, S.A.; Shain, D.H. A new species of Hirudo (Annelida: Hirudinidae): Historical biogeography of Eurasian medicinal leeches. BMC Zool. 2016, 1, 1-12. [CrossRef]

8. García, M.A. Atlas Climático Ibérico; Agencia Estatal de Meteorología—Instituto de Meteorologia de Portugal—Closas-Orcoyen SL: Madrid, Spain, 2011; pp. 1-8.

9. Taberlet, P.; Fumagalli, L.; Wust-Saucy, A.G.; Cosson, J.F. Comparative phylogeography and postglacial colonization routes in Europe. Mol. Ecol. 1998, 7, 453-464. [CrossRef]

10. Hewitt, G.M. Post-glacial re-colonization of European biota. Biol. J. Linn. Soc. 1999, 68, 87-112. [CrossRef]

11. Gómez, A.; Lunt, D.H. Refugia within refugia: Patterns of phylogeographic concordance in the Iberian Peninsula. In Phylogeography of Southern European Refugia. Evolutionary Perspectives on the Origins and Conservation of European Biodiversity; Weiss, S., Ferrand, N., Eds.; Springer: Dordrecht, Germany, 2007; pp. 155-188. [CrossRef]

12. Benovics, M.; Desdevises, Y.; Šanda, R.; Vukić, J.; Scheifler, M.; Doadrio, I.; Sousa-Santos, C.; Šimková, A. High diversity of fish ectoparasitic monogeneans (Dactylogyrus) in the Iberian Peninsula: A case of adaptive radiation? Parasitology 2020, 147, 418-430. [CrossRef]

13. Pastor y López, P. Apuntes Sobre la Fauna Asturiana Bajo su Aspecto Científico e Industrial; Imp. y Lit. de D. Benito González: Oviedo, Spain, 1859; pp. 1-44.

14. Johansson, L. Hirudineen aus dem nördlichen und ostlichen Spanien, gesammelt von Dr. F. Haas in den Jahren 1914-1919. Abh. Senckenb. Naturforsch. Ges. 1926, 39, 211-217.

15. García-Más, I.; Muñoz, B. Hirudo medicinalis Linnaeus, 1758. In Los Invertebrados no Insectos de la "Directiva Hábitat" en España; Ramos, M.A., Bragado, D., Fernández, J., Eds.; Ministerio de Medio Ambiente-Consejo Superior de Investigaciones Científicas: Madrid, Spain, 2001; pp. 125-130.

16. Ayres, C.; Comensaña-Iglesias, J. Leech presence on Iberian Brown Frog, Rana iberica (Amphibia: Anura: Ranidae) from north-western Spain. Acta Herpetol. 2008, 3, 155-159.

17. Muñoz, B.; Soriano, O. Hirudo medicinalis. In Bases Ecológicas Preliminares para la Conservación de las Especies de Interés Comunitario en España: Invertebrados; Ministerio de Agricultura, Alimentación y Medio Ambiente: Madrid, Spain, 2012 ; pp. 1-51.

18. Blanchard, R. Sanguijuelas de la Península Ibérica. An. Soc. Española Hist. Nat. 1893, 22, $234-258$.

19. Rivas-Mateos, M. El Hirudo troctina Johnson, de Extremadura. Boletín Real Soc. Española Hist. Nat. Sección Biológica 1901, 1, 175-377.

20. García-Más, I.; Jiménez, J.M. Introducción al estudio de las comunidades macrobentónicas de los ríos Asturianos: Hirudineos. Limnetica 1984, 1, 179-186.

21. Utevsky, S.Y.; Zinenko, A.I.; Atemasov, A.A.; Huseynov, M.A.; Utevska, O.M.; Utevsky, A.Y. New information on the distribution of the medicinal leech (genus Hirudo) in the Iberian Peninsula, the Caucasus and Central Asia. Lauterbornia 2008, 65, 119-130.

22. Kovalenko, M.V.; Utevsky, S.Y. Transitional morphology in hybrids of Hirudo verbana and H. orientalis (Clitellata, Hirudinida). Vestn. Zool. 2013, 47, 32-36. [CrossRef] 
23. Tessler, M.; de Carle, D.; Voiklis, M.L.; Gresham, O.A.; Neumann, J.S.; Cios, S.; Siddall, M.E. Worms that suck: Phylogenetic analysis of Hirudinea solidifies the position of Acanthobdellida and necessitates the dissolution of Rhynchobdellida. Mol. Phylogenet. Evol. 2018, 127, 129-134. [CrossRef]

24. Phillips, A.J.; Siddall, M.E. Poly-paraphyly of Hirudinidae: Many lineages of medicinal leeches. BMC Evol. Biol. 2009, 9, $246-257$. [CrossRef] [PubMed]

25. Pennak, R.W. Freshwater Invertebrates of United States; The Ronald Press Company: New York, NY, USA, 1953; pp. 1-769. [CrossRef]

26. Madoz, P. Diccionario Geográfico-Estadístico-Histórico de España y sus Posesiones de Ultramar; Establecimiento Tipográfico de P. Madoz y L. Sagasti: Madrid, Spain, 1850; Volume I-XVI, pp. 1-625.

27. Elliott, J.M.; Mann, K.H. A key to British Freshwater Leeches, with Notes on Their Life Cycles and Ecology; Freshwater Biological Association: Ambleside, UK, 1979; pp. 1-72.

28. Zurita, A.; García-Sánchez, A.M.; Cutillas, C. Ctenophthalmus baeticus boisseauorum (Beaucournu, 1968) and Ctenophthalmus apertus allani (Smit, 1955) (Siphonaptera: Ctenophthalmidae) as synonymous taxa: Morphometric, phylogenetic, and molecular characterization. Bull. Entomol. Res. 2020, 110, 663-676. [CrossRef] [PubMed]

29. Muñoz-Goyanes, G. Parque Nacional de la Montaña de Covadonga; SNPPC: Madrid, Spain, 1976; pp. 1-226.

30. Laborda, A.J. Fauna: Naturaleza Leonesa III; Edilesa: León, Spain, 1994; pp. 1-180.

31. Ocharan, F.J. Anélidos y otros grupos afines. In Zoología: Invertebrados; Anadón, E., Ed.; Júcar: Oviedo, Spain, 1981; pp. 107-109.

32. Sawyer, R.T. The Portuguese Leech Trade in the 19th Century: The First TransAtlantic Commerce in Medicinal Leeches. O Negócio Português de Sanguessugas no Século XIX: O Primeiro Comércio Transatlântico de Sanguessugas Medicinais. Anu. Cent. Estud. Hist. Atl. 2015, 7, 283-322.

33. Álvarez, D. Depredación de Mesotriton alpestris por Hirudo medicinalis en los Picos de Europa. Bol. Asoc. Herpetol. Esp. 2010, 21, 25-26.

34. Fernández-Bernaldo-de-Quirós, C. Contribución al estudio de las sanguijuelas (Hirudinea) de las aguas dulces de Asturias (N. de España). Bol. Cien. Natur. 1982, 30, 107-125.

35. García-Más, F.; Martínez, F.; Pujante, A. Sanguijuelas y moluscos de las aguas de La Mancha (España). Cuad. Estud. Manch. 1990, 21, 123-148.

36. Sawyer, R.T. Leech Biology and Behaviour; Oxford University Press: Oxford, UK, 1986; pp. 1-1065.

37. Folmer, O.; Black, M.; Hoen, W.; Lutz, R.; Vrijenhoek, R. DNA primers for amplification of mitochondrial cytochrome c oxidase subunit I from diverse metazoan invertebrates. Mol. Mar. Biol. Biotechnol. 1994, 3, 294-299.

38. Rozas, J.; Ferrer-Mata, A.; Sánchez-Del Barrio, J.C.; Guirao-Rico, S.; Librado, P.; Ramos-Onsins, S.E.; Sánchez-Gracia, A. DnaSP 6: DNA Sequence Polymorphism Analysis of Large Datasets. Mol. Biol. Evol. 2017, 34, 3299-3302. [CrossRef] [PubMed]

39. Kumar, S.; Stecher, G.; Tamura, K. MEGA7: Molecular Evolutionary Genetics Analysis Version 7.0 for Bigger Datasets. Mol. Biol. Med. 2016, 33, 1870-1874. [CrossRef] [PubMed]

40. Leigh, J.W.; Bryant, D. Popart: Full-feature software for haplotype network construction. Methods Ecol. Evol. 2015, 6, 1110-1116. [CrossRef]

41. Ronquist, F.; Teslenko, M.; van der Mark, P.; Ayres, D.L.; Darling, A.; Hohna, S.; Larget, B.; Liu, L.; Suchard, M.A.; Huelsenbeck, J.P. MrBayes 3.2: Efficient Bayesian phylogenetic inference and model choice across a large model space. Syst. Biol. $2012,61,539-542$. [CrossRef]

42. Lanfear, R.; Brett, C.; Simon, Y.W.H.; Stephane, G. PartitionFinder: Combined Selection of Partitioning Schemes and Substitution Models for Phylogenetic Analyses. Mol. Biol. Evol. 2012, 29, 1695-1701. [CrossRef]

43. Drummond, A.J.; Rambaut, A. BEAST: Bayesian evolutionary analysis by sampling trees. BMC Evol. Biol. 2007, 7, 214. [CrossRef]

44. Rambaut, A. FigTree v1.4.2. 2014. Available online: http:/ / tree.bio.ed.ac.uk/software/figtree/ (accessed on 17 June 2020).

45. Puillandre, N.; Lambert, A.; Brouillet, S.; Achaz, G. ABGD, Automatic Barcode Gap Discovery for primary species delimitation. Mol. Ecol. 2012, 21, 1864-1877. [CrossRef] [PubMed] 